\title{
A biomarker record of Lake El'gygytgyn, Far East Russian Arctic: investigating sources of organic matter and carbon cycling during marine isotope stages 1-3
}

\author{
A. R. Holland, S. T. Petsch, I. S. Castañeda, K. M. Wilkie, S. J. Burns, and J. Brigham-Grette \\ Department of Geosciences, University of Massachusetts Amherst, Amherst, MA 01003, USA \\ Correspondence to: A. R. Holland (aholland@geo.umass.edu)
}

Received: 5 September 2012 - Published in Clim. Past Discuss.: 20 September 2012

Revised: 18 December 2012 - Accepted: 21 December 2012 - Published: 30 January 2013

\begin{abstract}
Arctic paleoenvironmental archives serve as sensitive recorders of past climate change. Lake El'gygytgyn (Far East Russian Arctic) is a high-latitude crater impact lake that contains a continuous sediment record influenced by neither glaciation nor glacial erosion since the time of impact $3.58 \mathrm{Ma}$ ago. Prior research on sediments collected from Lake El'gygytgyn suggest times of permanent ice cover and anoxia corresponding to global glacial intervals, during which the sediments are laminated and are characterized by the co-occurrence of high total organic carbon, microscopic magnetite grains that show etching and dissolution, and negative excursions in bulk sediment organic matter carbon isotope $\left(\delta^{13} \mathrm{C}\right)$ values. Here we investigate the abundance and carbon isotopic composition of lipid biomarkers recovered from Lake El'gygytgyn sediments spanning marine isotope stages 1-3 to identify key sources of organic matter (OM) to lake sediments, to establish which OM sources drive the negative $\delta^{13} \mathrm{C}$ excursion exhibited by bulk sediment $\mathrm{OM}$, and to explore if there are molecular and isotopic signatures of anoxia in the lake during glaciation. We find that during marine isotope stages $1-3$, direct evidence for water column anoxia is lacking. A $\sim 4 \%$ negative excursion in bulk sediment $\delta^{13} \mathrm{C}$ values during the Local Last Glacial Maximum (LLGM) is accompanied by more protracted, higher magnitude negative excursions in $n$-alkanoic acid and $n$-alkanol $\delta^{13} \mathrm{C}$ values that begin $20 \mathrm{kyr}$ in advance of the LLGM. In contrast, $n$-alkanes and the $\mathrm{C}_{30} n$-alkanoic acid do not exhibit a negative $\delta^{13} \mathrm{C}$ excursion at this time. Our results indicate that the $\mathrm{C}_{24}, \mathrm{C}_{26}$ and $\mathrm{C}_{28} n$-alkanoic acids do not derive entirely from terrestrial OM sources, while the $\mathrm{C}_{30} n$-alkanoic acid at Lake El'gygytgyn is a robust indicator of terrestrial
\end{abstract}

OM contributions. Overall, our results strongly support the presence of a nutrient-poor water column, which is mostly isolated from atmospheric carbon dioxide during glaciation at Lake El'gygytgyn.

\section{Introduction}

Arctic lakes provide evidence of climate-sensitive environmental changes in terrestrial and aquatic ecosystems through accumulated sediment, which partially documents conditions of life and erosion within the lake basin. Arctic regions are particularly important recorders of past climate because summer temperatures in these regions hover near freezing. Thus, small changes in climate may cause large changes in environmental response (Vincent and Laybourn-Parry, 2008). Lake El'gygytgyn $\left(67^{\circ} 30^{\prime} \mathrm{N}, 172^{\circ} 05^{\prime} \mathrm{E}\right.$; Fig. 1$)$ is a $12-\mathrm{km}-$ wide, 175 -m-deep crater impact lake dated to $3.58 \pm 0.04 \mathrm{Ma}$ (Layer, 2000) that contains a continuous record of sedimentation (Brigham-Grette et al., 2007; Gebhardt et al., 2006). Like much of Beringia, the crater and surrounding region have not been glaciated or subject to glacial erosion since impact (Brigham-Grette et al., 2004). Unlike many Arctic lakes that contain discontinuous, glacially disturbed sediment archives, Lake El'gygytgyn provides a long-term, continuous record of climate and ecosystem change in the high Arctic from Pliocene to the present. In order to interpret this record, it is essential to understand how the ecology of the lake and its surroundings are expressed in the sedimentary record. Prior to deep drilling in 2009, several short pilot cores were collected to gain initial insights into 


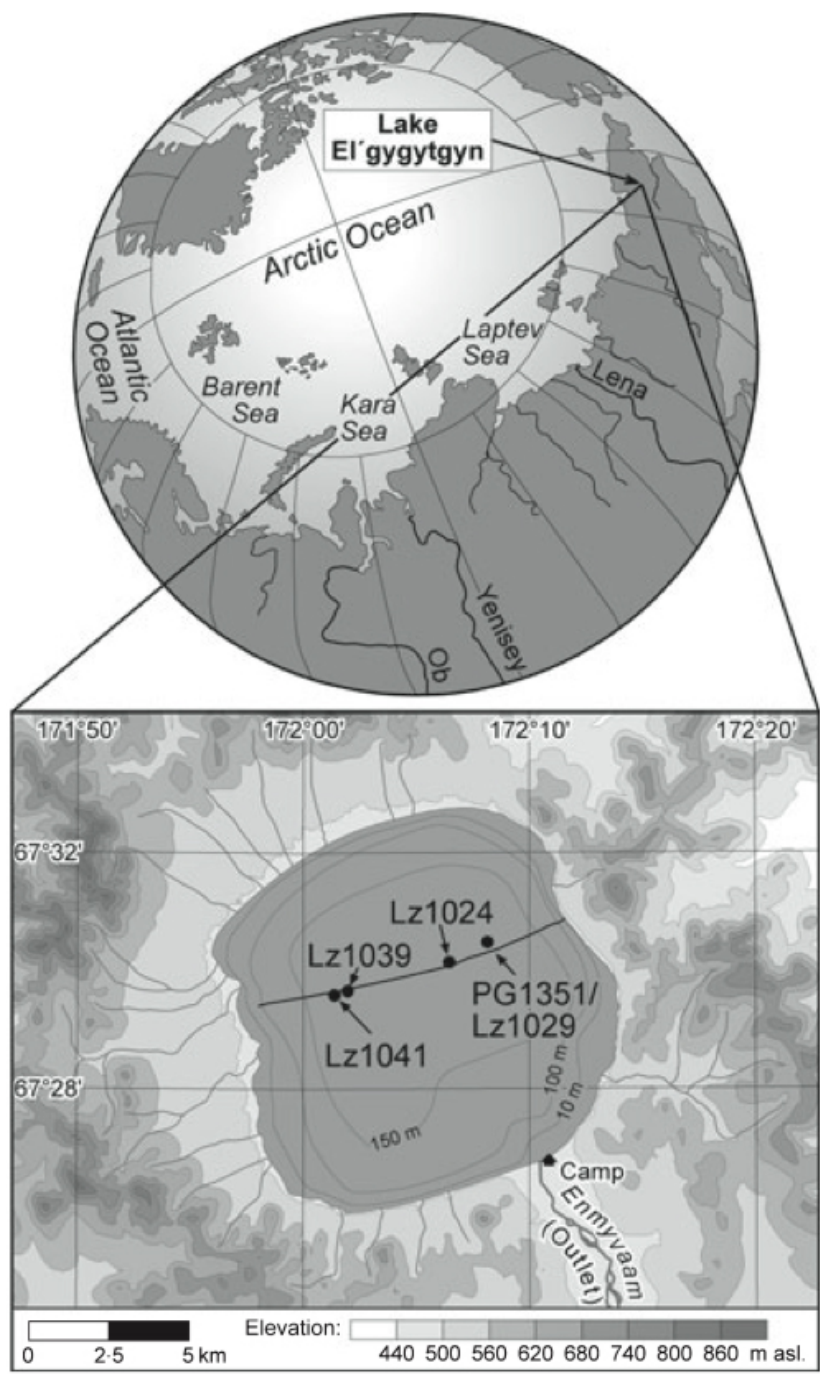

Fig. 1. Lake El'gygytgyn site location $\left(67^{\circ} 30^{\prime} \mathrm{N}, 172^{\circ} 05^{\prime} \mathrm{E}\right)$ and the location of core LZ1029 in relationship to other nearby sediment cores referred to in the text.

glacial-interglacial variability. These pilot studies, spanning up to the past $250 \mathrm{kyr}$, have revealed large cyclic changes in sedimentary geochemistry, such as percent of total organic carbon (TOC), carbon isotopic measurements of TOC $\left(\delta^{13} \mathrm{C}_{\mathrm{TOC}}\right)$, and magnetic susceptibility (Melles et al., 2007; Nowaczyk et al., 2007). These changes are closely tied to regional climate variables and thought to be largely regulated by the extent and timing of ice cover at the lake (Melles et al., 2007). However, the degree to which variations in aquatic productivity, water column anoxia, or methanogenesis may have impacted the sedimentary record is not well understood. This study explores the shifting biogeochemical conditions within the lake during marine isotope stages (MIS) 1-3 in relation to changing ice cover and the associated impacts to carbon cycling and changes in availability of atmospheric gases to the lake water.
At present, Lake El'gygytgyn is ice-covered for the majority of the year, with up to 3 months of open water (midJuly to mid-October) (Nolan et al., 2002). Previous studies have linked the large changes in bulk geochemistry with permanent (year-round) ice cover during glacial intervals that, with reduced potential for resupply of atmospheric oxygen, might have led to severe water column anoxia. For example, Nowaczyk et al. (2007) proposed that extreme shifts in magnetic susceptibility might represent dissolution of magnetite grains during anoxia. This interpretation is supported by the co-occurrence of laminated sediments, suggesting minimal bioturbation due to anoxic conditions (Melles et al., 2007), and inspection of microscopic magnetite grains that show etching and dissolution (Murdock et al., 2012).

This study examines bulk, molecular and isotopic characteristics of Lake El'gygytgyn sediments from a pilot core spanning the past $63 \mathrm{kyr}$, in an effort to better understand inputs of $\mathrm{OM}$ to lake sediments, to constrain which compounds and $\mathrm{OM}$ sources exhibit $\delta^{13} \mathrm{C}$ characteristics similar to the TOC record, and to seek molecular and isotopic evidence for anoxia. The last glacial-interglacial transition is a time interval for which climatic changes globally and at Lake El'gygytgyn have been well documented (Brigham-Grette et al., 2007; Melles et al., 2007) and therefore provides a paleoclimate context in which to evaluate and compare the biogeochemical data produced here. Bulk sedimentary $\delta^{15} \mathrm{~N}$ values are employed as a possible proxy for denitrification and anoxic intensity. Lipid biomarkers are identified to constrain contributions of terrestrial and aquatic OM to lake sediments. Compound-specific $\delta^{13} \mathrm{C}$ analysis of lipid biomarkers is used to investigate the source of a strong negative isotopic shift in the bulk sediment $\delta^{13} \mathrm{C}$ during glacial intervals. Specifically, two questions are posed: (1) is there specific evidence for anoxia in the water column during glacial intervals at Lake El'gygytgyn? and (2) what organic matter source(s) drive the ${ }^{13} \mathrm{C}$-depleted bulk sediment isotopic signature during the interpreted glacial intervals?

In this study, the term Local Last Glacial Maximum (LLGM; approximately 20-25 ka) is used to refer to the period of most extreme changes in bulk geochemistry data, including shifts in magnetic susceptibility, TOC, and bulk $\delta^{13} \mathrm{C}$. "Local" is meant to differentiate this region from other areas of the Arctic impacted by glacial activity, given that regional cooling in the area of Lake El'gygytgyn may or may not have been entirely synchronous with glacial activity in other parts of the Arctic. Three additional intervals are defined herein due to broader periods of molecular variability apparent in this study, but not observed previously in the bulk geochemical data. 


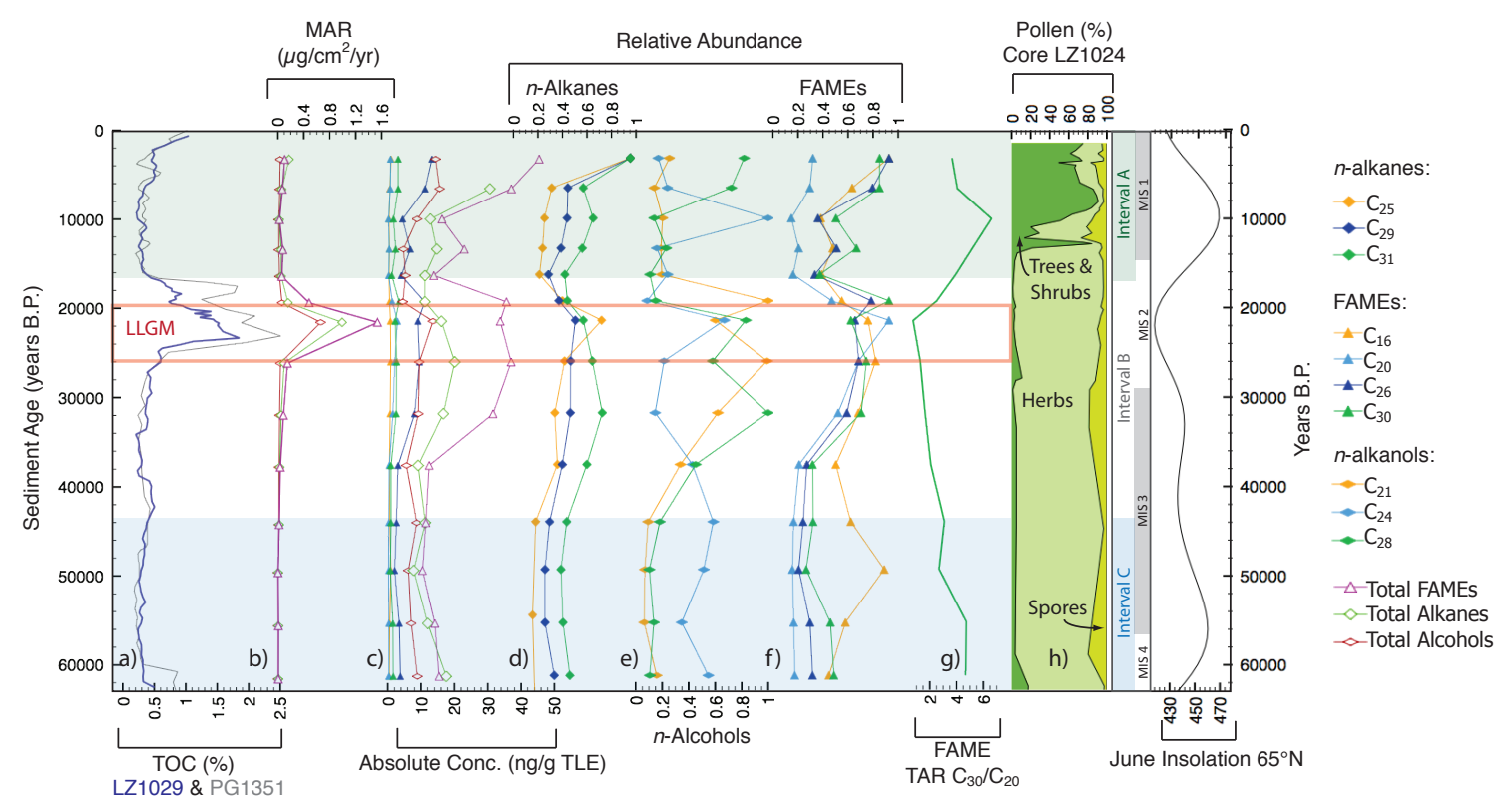

Fig. 2. Concentrations of $n$-alkanes, FAMEs and $n$-alkanols relative to TOC. Compound concentrations are represented in various configurations: (a) TOC content for both cores PG1351 (grey) and LZ1029 (blue), (b) mass accumulation rates of major compound groups, (c) absolute concentrations of representative FAMEs and total $n$-alkanols, $n$-alkanes, and FAMEs. Relative abundances of $n$-alkanes, $n$ alkanols, and FAMEs are plotted in (d), (e), and (f), respectively. (g) FAME terrigenous-aquatic ratio based on the $\mathrm{C}_{30}$ and $\mathrm{C}_{20} \mathrm{FAMEs}_{3}$ and (h) pollen data from nearby core LZ1024 (Lozhkin et al., 2007). Summer insolation at $65^{\circ} \mathrm{N}$ is shown (Berger and Loutre, 1991). The orange box denotes LLGM.

\section{Methods and background}

\subsection{Sampling}

Sediment core LZ1029 was recovered in 2003 from $175 \mathrm{~m}$ water depth using a gravity corer and a 3-m-long percussion piston corer, which captured a composite sequence of several overlapping sections (Swann et al., 2010; Juschus et al., 2009). The section used for this study, LZ1029-7 is $2.91 \mathrm{~m}$ in length. This study also references previously published data from nearby pilot cores PG1351 and LZ1024, collected in 1998 and 2003, respectively (Brigham-Grette et al., 2007; Melles et al., 2007; Juschus et al., 2007). LZ1029 spans approximately the past $63 \mathrm{kyr}$ and was taken at the same location as PG1351, while LZ1024 is located approximately $2 \mathrm{~km}$ southwest closer to the center of the lake.

\subsection{Core LZ1029 chronology}

The chronology of LZ1029 was established by Murdock et al. (2012) based on correlation to the other sections of composite core LZ1029 $(-5,-8,-9)$ and core PG1351 based on sedimentology and stratigraphic markers (e.g. turbidites) and similar trends in TOC (Fig. 2a) and bulk $\delta^{13} \mathrm{C}$. The lowermost sample described in this paper extends beyond the Murdock et al. (2012) age model, and thus the age of this sample is uncertain. The age model for core PG1351 is based on the infrared stimulated luminescence (IRSL) dating of the core sediments and the magnetic susceptibility record tuned to July insolation at $70^{\circ} \mathrm{N}$, supported by other geochemical, pollen, and diatom data (Forman et al., 2007; Frank et al., 2012; Nowaczyk et al., 2002, 2007).

\subsection{Bulk sediment analysis}

The TOC and magnetic susceptibility records for core LZ1029 are described in Murdock et al. (2012). TOC $\delta^{13} \mathrm{C}$ values were determined on acidified $\left(1 \mathrm{~N} \mathrm{H}_{2} \mathrm{SO}_{3}\right)$ sediment samples by online combustion using a Costech elemental combustion system (ECS140 EA) interfaced to a Thermo Delta V isotope-ratio mass spectrometer (EA-irMS). Bulk sediment $\delta^{15} \mathrm{~N}$ values were determined on the same instrument, using samples that were not acidified. Analyses were run in triplicate and are reported relative to the Vienna Pee Dee Belemnite (VPDB) standard in per mil (\%o) notation for $\delta^{13} \mathrm{C}$, and relative to atmospheric nitrogen $\left(\delta^{15} \mathrm{~N}=0 \%\right.$ ) for $\delta^{15} \mathrm{~N}$ values. Replicate analysis of acetanilide $\left(\delta^{13} \mathrm{C}=-30.11 \%\right.$ o $)$ yielded an average value of $-29.72 \%$ o $(n=18)$ with one standard deviation of $\pm 0.9 \%$, and replicate analysis of sucrose $\left(\delta^{13} \mathrm{C}=-10.45 \% \circ\right)$ yielded an average value of $-12.57 \%$ o $(n=15)$ with one standard deviation of $\pm 1.1 \%$. Throughout sample analysis, 17 replicates of USGS25 ammonium sulfate $\left(\delta^{15} \mathrm{~N}=-30.4 \%\right.$ ) yielded an average value of $-30.3 \%$ with one standard deviation of $\pm 0.3 \%$ and 20 replicates of IAEA-N1 ammonium 
sulfate $\left(\delta^{15} \mathrm{~N}=0.4 \%\right.$ o $)$ yielded an average of $0.45 \%$ with one standard deviation of $\pm 0.24 \%$.

\subsection{Lipid analysis}

14 samples (4.7-11.8 g) were selected for biomarker analysis from core LZ1029. All analyses were conducted at the UMass Biogeochemistry Laboratory, except as noted. Freeze-dried and homogenized sediment (to which $20 \mu \mathrm{g}$ of $\mathrm{C}_{36} n$-alkane was added), was extracted with a $9: 1$ dichloromethane (DCM) : methanol (MeOH) (vol: vol) solution in an accelerated solvent extractor (Dionex ASE 200). Total lipid extracts were separated by column chromatography into neutral (DCM : isopropyl alcohol, $2: 1$ ) and acid (2\% formic acid in DCM) fractions using aminopropyl columns. The neutral fraction was further separated by silica gel column chromatography into four fractions: hydrocarbons (hexane); aldehydes/ketones (DCM); alcohols and sterols (3:1 hexane: ethyl acetate); and more polar compounds $(\mathrm{MeOH})$. The acid fractions and an external isotope mass balance standard (heneiocosanoic acid) were methylated with $\mathrm{BF}_{3}$-methanol to convert $n$-alkanoic acids to fatty acid methyl esters (FAMEs), which were purified on a silica gel column. The alcohol fractions, along with two external isotope mass balance standards (nonadecanol and octacosanol), were derivatized with N,Obis(trimethylsilyl)trifluoroacetamide (BSTFA) to convert alcohols to trimethylsilyl (TMS) ethers. The $\mathrm{C}_{36} n$-alkane $(20 \mu \mathrm{g})$ was added to FAME and TMS-alcohol fractions for quantification. Identical lot numbers of $\mathrm{BF}_{3}-\mathrm{MeOH}$ and BSTFA were used in derivatization of standards and analytes, to correct for the isotopic contribution of carbon atoms added during derivatization.

FAMEs, $n$-alkanes and TMS-esters of $n$-alkanols were identified on a Hewlett Packard (HP) 6890 series GC-mass selective detector (GC-MSD) equipped with a $5 \%$ phenyl methyl siloxane column (HP-5MS, $30 \mathrm{~m} \times 0.25 \mathrm{~mm}$ i.d., film thickness $0.25 \mu \mathrm{m})$. Positive identification was achieved by comparing mass fragmentation patterns and relative retention times with those from a mass spectral database and published literature. FAMEs, $n$-alkanes and TMS-esters of $n$-alkanols were quantified using a Hewlett Packard (HP) 6890 series gas chromatograph-flame ionization detector (GC-FID) equipped with a $5 \%$ phenyl methyl siloxane capillary column $(30 \mathrm{~m} \times 0.25 \mathrm{~mm}$ i.d., film thickness $0.25 \mu \mathrm{m})$. Temperature programs for all fractions and instrument runs are reported in Table 1.

We report biomarker concentrations in terms of amount compound per gram total lipid extract (ng g ${ }^{-1}$ TLE) noting that the extractable component of sedimentary OM (the TLE) is a small portion of the TOC. Therefore the significance of compound concentration, and implications for processes and happenings within the lake, referenced against TLE is appropriate. We note that trends in biomarker data are very similar when normalized to g TLE or g TOC (see Supplement).
Compound-specific $\delta^{13} \mathrm{C}$ analyses of FAMEs, $n$-alkanes and TMS-esters of $n$-alkanols were conducted at Yale University's Earth System Center for Stable Isotopic Studies. Single run samples were analyzed on a Thermo Scientificcombustion interface GC (Trace GC Ultra 2000), coupled to a Thermo Scientific Finnigan MAT 253 stable-isotope ratio mass spectrometer (GC-irMS) and equipped with a DB-1 column $(60 \mathrm{~m} \times 250 \mu \mathrm{m}$ i.d., $0.25 \mu \mathrm{m}$ film thickness). A standard mixture consisting of five $n$-alkanes $\left(\mathrm{C}_{20}, \mathrm{C}_{25}\right.$, $\mathrm{C}_{27}, \mathrm{C}_{30}$, and $\mathrm{C}_{38}$ with known $\delta^{13} \mathrm{C}$ values, "Mix A" from Arndt Schimmelman, Indiana University) was analyzed daily at several concentrations to ensure accuracy following the methods outlined in Tipple and Pagani (2010). In addition, a $\mathrm{C}_{36} n$-alkane of known $\delta^{13} \mathrm{C}(-29.88 \%$ o) was added to each sample and used to correct individual isotope ratios. Results are expressed as $\delta$ notation, where $\delta^{13} \mathrm{C}=$ $\left[\left(R_{\text {sample }} / R_{\text {standard }}\right)-1\right] \times 1000 ; R={ }^{13} \mathrm{C} /{ }^{12} \mathrm{C}$, and the standard is VPDB $\left(\delta^{13} \mathrm{C}=0 \%\right.$ ).$\delta^{13} \mathrm{C}$ values are corrected for the addition of carbon atoms on derivatization, specifically the single methyl carbon atom of FAMEs and the three methyl carbon atoms of TMS ethers of alcohols. For $n$-alkane (13 replicates) and $n$-alkanol fractions ( 15 replicates) the average isotopic values were within one standard deviation (< $0.66 \%$ ) of the known $\delta^{13} \mathrm{C}_{\mathrm{C} 36}$ value. FAME replicates (14) consistently displayed values outside one standard deviation (average $\delta^{13} \mathrm{C}_{\mathrm{C} 36}=-30.54 \%$, Std. dev. $=0.25 \%$ ). Therefore, FAME values were reevaluated by correcting the internal standard to the known $\delta^{13} \mathrm{C}_{\mathrm{C} 36}$ value and adjusting other values in each sample accordingly, an average adjustment of $+0.658 \%$.

Following analysis by GC, GC-MS, and GC-IRMS, the alcohol fraction was underivatized by shaking with ultrapure water and extracting the water 4 times with DCM. A known quantity of an internal standard, a $\mathrm{C}_{46}$ glycerol dialkyl glycerol tetraether (GDGT), was added. These fractions were subsequently filtered through a $0.45 \mu \mathrm{m}$ PTFE syringe filter in 99: 1 hexane : propanol and analyzed on an Agilent 1260 HPLC coupled to an Agilent 6120 MSD, for identification and quantification of GDGTs following the methods following the methods of Hopmans et al. (2000), with minor modifications (Schouten et al., 2007). Separation was achieved on a Prevail Cyano column $(150 \mathrm{~mm} \times 2.1 \mathrm{~mm}, 3 \mathrm{~mm})$ using 99: 1 hexane : propanol (vol: vol) as an eluent. After the first $7 \mathrm{~min}$, the eluent increased by a linear gradient up to $1.8 \%$ isopropanol (vol) over the next $45 \mathrm{~min}$ at a flow rate of $0.2 \mathrm{ml} \mathrm{min}^{-1}$. Scanning was performed in selected ion monitoring (SIM) mode.

\subsection{Background information - lipid biomarkers}

In this study we examine a number of compound classes, some of which are attributed to either terrestrial or aquatic sources. Long-chain $\left(\mathrm{C}_{24}-\mathrm{C}_{28}\right)$ FAMEs, $n$-alkanes, and $n$ alkanols are commonly assigned a terrestrial source (e.g., Tierney et al., 2010b; Castañeda and Schouten, 2011 and 
Table 1. Temperature conditions for GC, GC-MS and GC-IRMS for the different compound classes examined in this study.

\begin{tabular}{|c|c|c|c|c|c|c|c|}
\hline Fraction & $\begin{array}{l}\text { Initial } \\
\text { Temp }\end{array}$ & $\begin{array}{l}\text { Hold } \\
\text { Time }\end{array}$ & Ramp 1 & Ramp 2 & Ramp 3 & Ramp 4 & $\begin{array}{l}\text { Final } \\
\text { Temp hold }\end{array}$ \\
\hline $\begin{array}{l}n \text {-alkane } \\
\text { (GC-FID) }\end{array}$ & $60^{\circ} \mathrm{C}$ & $1 \mathrm{~min}$ & $\begin{array}{l}15^{\circ} \mathrm{Cmin}^{-1} \\
\text { to } 315^{\circ} \mathrm{C}\end{array}$ & & & & $15 \mathrm{~min}$ \\
\hline $\begin{array}{l}n \text {-alkanol } \\
(\mathrm{GC}-\mathrm{FID})\end{array}$ & $60^{\circ} \mathrm{C}$ & $2 \min$ & $\begin{array}{l}20^{\circ} \mathrm{C} \mathrm{min}^{-1} \\
\text { to } 160^{\circ} \mathrm{C}\end{array}$ & $\begin{array}{l}4{ }^{\circ} \mathrm{Cmin}^{-1} \\
\text { to } 320^{\circ} \mathrm{C}\end{array}$ & & & $15 \mathrm{~min}$ \\
\hline $\begin{array}{l}\text { FAME } \\
\text { (GC-FID) }\end{array}$ & $60^{\circ} \mathrm{C}$ & $2 \min$ & $\begin{array}{l}15^{\circ} \mathrm{Cmin}^{-1} \\
\text { to } 315^{\circ} \mathrm{C}\end{array}$ & & & & $10 \mathrm{~min}$ \\
\hline $\begin{array}{l}n \text {-alkane } \\
\text { (GC-MS) }\end{array}$ & $40^{\circ} \mathrm{C}$ & $0 \mathrm{~min}$ & $\begin{array}{l}6^{\circ} \mathrm{Cmin}^{-1} \\
\text { to } 320^{\circ} \mathrm{C}\end{array}$ & & & & $2 \min$ \\
\hline $\begin{array}{l}n \text {-alkanol } \\
(\mathrm{GC}-\mathrm{MS})\end{array}$ & $60^{\circ} \mathrm{C}$ & $0 \mathrm{~min}$ & $\begin{array}{l}20^{\circ} \mathrm{C} \mathrm{min}^{-1} \\
\text { to } 160^{\circ} \mathrm{C}\end{array}$ & & & & $15 \mathrm{~min}$ \\
\hline $\begin{array}{l}\text { FAME } \\
(\mathrm{GC}-\mathrm{MS})\end{array}$ & $40^{\circ} \mathrm{C}$ & $2 \mathrm{~min}$ & $\begin{array}{l}6{ }^{\circ} \mathrm{Cmin}^{-1} \\
\text { to } 320^{\circ} \mathrm{C}\end{array}$ & & & & $2 \min$ \\
\hline $\begin{array}{l}n \text {-alkane } \\
(\mathrm{GC} \text {-irMS) }\end{array}$ & $115^{\circ} \mathrm{C}$ & $2 \mathrm{~min}$ & $\begin{array}{l}16^{\circ} \mathrm{Cmin}^{-1} \\
\text { to } 145^{\circ} \mathrm{C}\end{array}$ & $\begin{array}{l}12^{\circ} \mathrm{Cmin}^{-1} \\
\text { to } 200^{\circ} \mathrm{C}\end{array}$ & $\begin{array}{l}8^{\circ} \mathrm{Cmin}^{-1} \\
\text { to } 290^{\circ} \mathrm{C}\end{array}$ & $\begin{array}{l}3{ }^{\circ} \mathrm{Cmin}^{-1} \\
\text { to } 325^{\circ} \mathrm{C}\end{array}$ & $13.62 \mathrm{~min}$ \\
\hline $\begin{array}{l}\text { FAME } \\
\text { (GC-irMS }\end{array}$ & $80^{\circ} \mathrm{C}$ & $2 \min$ & $\begin{array}{l}12^{\circ} \mathrm{Cmin}^{-1} \\
\text { to } 145^{\circ} \mathrm{C}\end{array}$ & $\begin{array}{l}12^{\circ} \mathrm{Cmin}^{-1} \\
\text { to } 200^{\circ} \mathrm{C}\end{array}$ & $\begin{array}{l}8^{\circ} \mathrm{C} \mathrm{min}^{-1} \\
\text { to } 290^{\circ} \mathrm{C}\end{array}$ & $\begin{array}{l}3{ }^{\circ} \mathrm{Cmin}^{-1} \\
\text { to } 325^{\circ} \mathrm{C}\end{array}$ & $11 \mathrm{~min}$ \\
\hline $\begin{array}{l}n \text {-alkanol } \\
\text { (GC-irMS) }\end{array}$ & $80^{\circ} \mathrm{C}$ & $2 \min$ & $\begin{array}{l}20^{\circ} \mathrm{C} \mathrm{min}^{-1} \\
\text { to } 200^{\circ} \mathrm{C}\end{array}$ & $\begin{array}{l}4^{\circ} \mathrm{C} \mathrm{min}^{-1} \\
\text { to } 325^{\circ} \mathrm{C}\end{array}$ & & & $15 \mathrm{~min}$ \\
\hline
\end{tabular}

references therein) as these compounds are major components of leaf waxes (Eglinton and Hamilton, 1967). In contrast, short-chain $n$-alkanes (17-21 carbon atoms), $n$ alkanoic acids, and $n$-alkanols provide a general biomarker for aquatic algae (Giger et al., 1980; Cranwell et al., 1987) while mid-chain $n$-alkanes (23-25 carbon atoms) are produced by aquatic macrophytes (Ficken et al., 2000). Several other groups of compounds are often used as biomarkers for aquatic algae. Sterols (compounds that occur in all eukaryotes) are membrane rigidifiers, and the specificity of these compounds for different phytoplankton groups is well known (Volkman, 1986; Volkman et al., 1998). For example, the compound dinosterol (4a,23,24-trimethyl-5acholest-22-en-3b-ol) is found in many dinoflagellate species (Boon et al., 1979; Withers, 1983; Pirretti et al., 1997) while long-chain $\left(\mathrm{C}_{28}\right.$ and $\left.\mathrm{C}_{32}\right) 1,15 n$-alkyl diols are produced by Eustigmatophyte (yellow-green) algae (Volkman et al., 1992; Versteegh et al., 1997), and possibly cyanobacteria (Xu et al., 2007). Isoprenoid glycerol dialkyl glygerol tetraethers (GDGTs) are produced by aquatic Thaumarchaeota, mesophilic members of the archaea, and are found in marine and lacustrine water columns (e.g. Schouten et al., 2002; Castañeda and Schouten, 2011). Branched GDGTs are thought to be produced by anaerobic soil bacteria (Weijers et al., 2007), possibly Acidobacteria (Sinninghé Damste et al., 2011), although uncertainty remains regarding the source organism(s). Both isoprenoid and branched GDGTs are of particular interest because they provide proxies for reconstructing past temperature. For a more detailed discussion of biomarkers and their sources in lake sediments, refer to Castañeda and Schouten (2011).

\section{Results}

\subsection{Bulk geochemical data}

As reported in Murdock et al. (2012), TOC concentrations in core LZ1029 range from $0.2-1.8 \%$ (Fig. 2). TOC concentrations in LZ1029 are similar to those reported for core PG1351 (Melles et al., 2007) throughout much of the record from modern through MIS 3, with highest TOC concentrations found in a narrow range of sediments corresponding to the LLGM. TOC $\delta^{13} \mathrm{C}$ values in core LZ1029 range from $-25.0 \%$ to $-32.6 \%$ (Fig. 3). The lowest $\delta^{13} \mathrm{C}$ values correspond to samples with the highest TOC concentrations. However, TOC $\delta^{13} \mathrm{C}$ values begin to gradually decline at approximately $43 \mathrm{ka}, \sim 20 \mathrm{kyr}$ in advance of the sharp \% TOC increase observed at the LLGM (Figs. 2 and 3). Bulk sediment $\delta^{15} \mathrm{~N}$ values in core LZ1029 range between $1.5 \%$ and $4.5 \%$, increasing from $\sim 3-3.5 \%$ in the lower portion of the core to approximately $4.5 \%$ o between $35-30 \mathrm{ka}$ (Fig. 4). This high is followed by a rapid decrease in $\delta^{15} \mathrm{~N}$ values to approximately $2 \%$ during the LLGM, with a slight increase in $\delta^{15} \mathrm{~N}$ values to approximately $2.5 \%$ after $17 \mathrm{ka}$. While these changes 


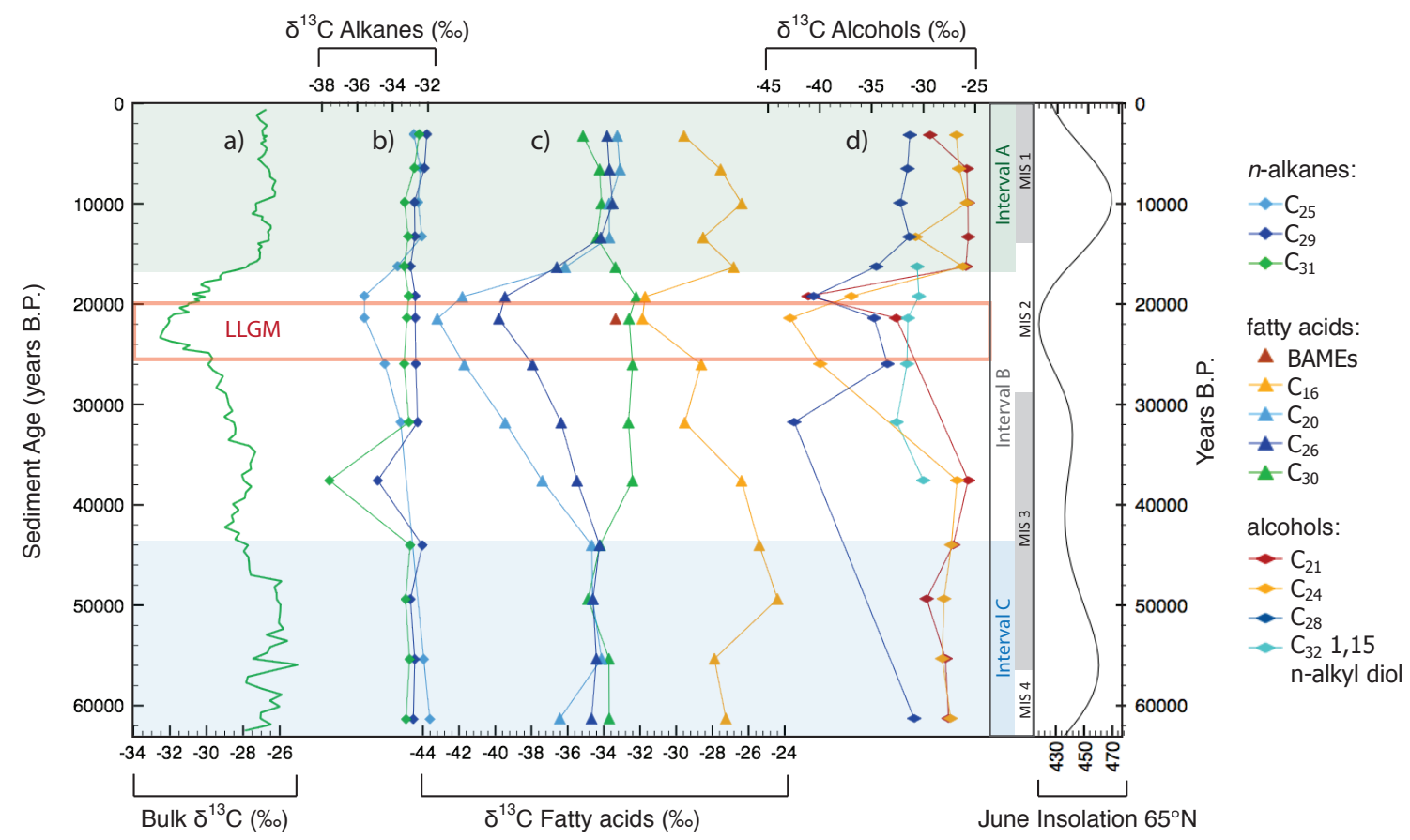

Fig. 3. (a) Bulk and compound-specific $\delta^{13} \mathrm{C}$ values of representative (b) $n$-alkanes, (c) fatty acids, and (d) $n$-alkanols. Summer insolation at $65^{\circ} \mathrm{N}$ is shown (Berger and Loutre, 1991). The orange box denotes LLGM.

in $\delta^{15} \mathrm{~N}$ values appear to mirror those in $\% \mathrm{TOC}$ and magnetic susceptibility (Fig. 4), and are broadly similar to the TOC $\delta^{13} \mathrm{C}$ record, $\delta^{15} \mathrm{~N}$ values show poor linear correlation with both $\delta^{13} \mathrm{C}\left(r^{2}=0.13, p=0.048, n=29\right)$ and \% TOC $\left(r^{2}=0.30, p=0.0023, n=29\right)$.

\subsection{Abundance and isotopic composition of lipid biomarkers}

\subsection{1 n-Alkanes}

Core LZ1029 contains a suite of $n$-alkanes ranging from 21 to 33 carbons in length. Total $n$-alkane concentrations range from $7.8 \mathrm{ng} \mathrm{g}^{-1}$ TLE in the lower portion of the core to $70.7 \mathrm{ng} \mathrm{g}^{-1}$ TLE in the most recent sample, displaying a gradual increase around $43 \mathrm{ka}$ to a $20.1 \mathrm{ng} \mathrm{g}^{-1}$ TLE peak during the LLGM (Fig. 2d). Representative compounds are shown on Figs. 2 and 3 (see Supplement for full dataset). The $\mathrm{C}_{29}$ and $\mathrm{C}_{31} n$-alkanes are the most abundant throughout much of core LZ1029, but $\mathrm{C}_{21}, \mathrm{C}_{23}$ and $\mathrm{C}_{25}$ are more abundant during the LLGM (see $\mathrm{C}_{25} n$-alkane, Fig. 2d). The relative abundance of the $\mathrm{C}_{23}$ to $\mathrm{C}_{29} n$-alkanes generally follows trends in \% TOC with highest values confined to the LLGM, while $\mathrm{C}_{31}$ and $\mathrm{C}_{33}$ display a distinctly different pattern, displaying maxima in concentrations prior to the LLGM around $32 \mathrm{ka}$ (see $\mathrm{C}_{29}$ and $\mathrm{C}_{31}$ n-alkanes, Fig. 2d; similarly noted in Wilkie, 2012).

Isotopic values of $n$-alkanes $\mathrm{C}_{27}-\mathrm{C}_{33}$ are consistently lower than TOC $\delta^{13} \mathrm{C}$ values in LZ1029 (see $\mathrm{C}_{29}$ and $\mathrm{C}_{31}$ $n$-alkanes, Fig. $3 \mathrm{~b}$ ), but do not parallel the approximately $6 \%$ negative excursion observed in the TOC $\delta^{13} \mathrm{C}$ record during the LLGM. $\mathrm{C}_{27}-\mathrm{C}_{33} \delta^{13} \mathrm{C}$ values are relatively constant at approximately $-34 \%$ o throughout the core, displaying lower $\delta^{13} \mathrm{C}$ values in one sample at $38 \mathrm{ka}$ (approximately $-40 \%$ ) but no obvious isotope excursion during the LLGM. In contrast, $\mathrm{C}_{25} n$-alkane $\delta^{13} \mathrm{C}$ values are approximately $2 \%$ o lower during the LLGM (Fig. 3b).

\subsubsection{FAMEs}

Core LZ1029 contains a suite of $n$-alkanoic acids ranging between 14 and 32 carbon atoms in size with the $C_{26}$ FAME being the most abundant. Total FAME concentrations range from $8.6 \mathrm{ng} \mathrm{g}^{-1}$ TLE in the lower portion of the core to $34.9 \mathrm{ng} \mathrm{g}^{-1}$ TLE during the LLGM and peak at $43.0 \mathrm{ng} \mathrm{g}^{-1}$ TLE in the most recent sample (Fig. 2c). Odd carbon-number FAMEs are much less abundant than evennumbered FAMEs, and methyl-branched iso- and anteisofatty acids are detected only in the sample with the highest \%TOC. Short- $\left(\mathrm{C}_{16}-\mathrm{C}_{18}\right)$ and mid-chain $\left(\mathrm{C}_{20}-\mathrm{C}_{22}\right)$ FAMEs reach maximum abundance during the LLGM, similar to TOC concentrations, while long-chain FAMEs $\left(\mathrm{C}_{24}-\mathrm{C}_{30}\right)$ increase in abundance well before the LLGM (Fig. 2f; other $n$-alkanoic acids in Supplement; similarly noted in Wilkie, 2012).

Isotope analysis of $n$-alkanoic acids from LZ1029 reveals complex patterns in $\delta^{13} \mathrm{C}$ values. The record of the $\mathrm{C}_{30} n$ alkanoic acid $\delta^{13} \mathrm{C}$ values is most similar to that of $n$-alkanes, 


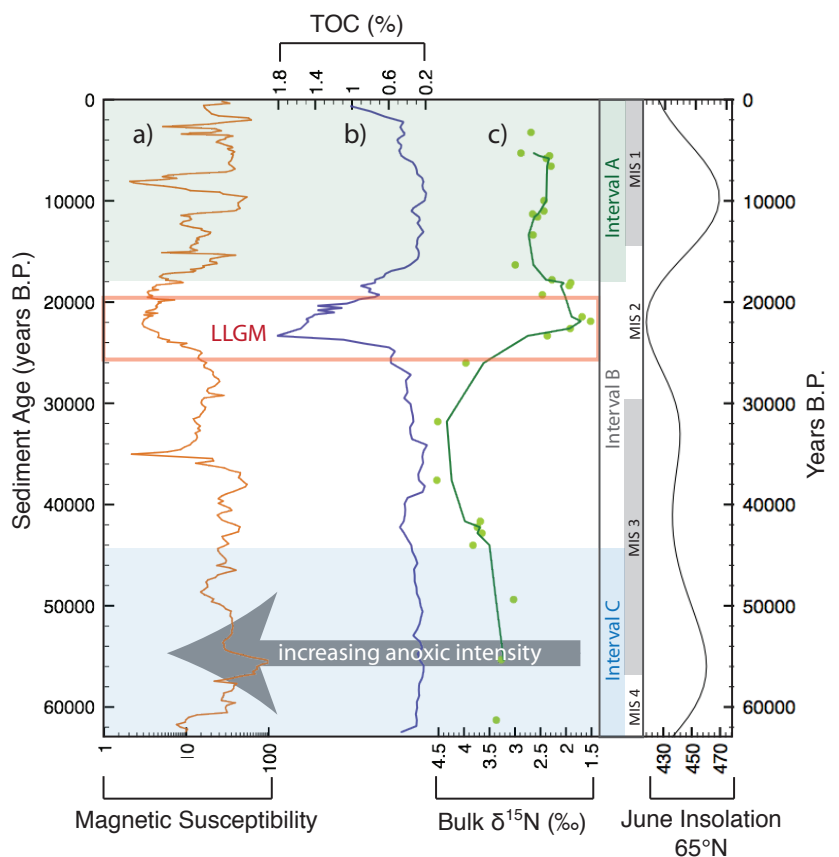

Fig. 4. (a) Magnetic susceptibility (Murdock et al., 2012) relative to (b) TOC (Murdock et al., 2012) and (c) bulk $\delta^{15} \mathrm{~N}$. Green line denotes 3-point running mean. Note that the $\mathrm{x}$-axis scale for TOC is reversed. Summer insolation at $65^{\circ} \mathrm{N}$ is shown (Berger and Loutre, 1991). The orange box denotes LLGM.

with nearly constant values close to $-34 \%$ o throughout much of the core; an approximately $2 \%$ increase in $\mathrm{C}_{30} \delta^{13} \mathrm{C}$ values is observed prior to and during the LLGM (Fig. 3c). The $\delta^{13} \mathrm{C}$ values of the $\mathrm{C}_{16}$ and $\mathrm{C}_{18} n$-alkanoic acids are similar to TOC $\delta^{13} \mathrm{C}$ values throughout the core, and show an approximately $6 \%$ negative excursion beginning approximately $43 \mathrm{ka}$ and peaking during the LLGM (see $\mathrm{C}_{16} n$ alkanoic acid, Fig. 3c). This is paralleled by an approximately $4 \%$ negative excursion in $\delta^{13} \mathrm{C}$ values of mid-chain $\left(\mathrm{C}_{20}\right.$ and $\left.\mathrm{C}_{22}\right) n$-alkanoic acids, and an approximately $8 \%$ negative excursion in $\delta^{13} \mathrm{C}$ values of long-chain $\left(\mathrm{C}_{24}, \mathrm{C}_{26}\right.$ and $\mathrm{C}_{28}$ ) $n$-alkanoic acids (see $\mathrm{C}_{20}$ and $\mathrm{C}_{26} n$-alkanoic acids, Fig. 3c); for both mid- and long-chain $n$-alkanoic acids, $\delta^{13} \mathrm{C}$ values prior to excursion are similar to the $\mathrm{C}_{30} \delta^{13} \mathrm{C}$ values and reach minimum values during the LLGM that are lower than the TOC $\delta^{13} \mathrm{C}$ record. For the $\mathrm{C}_{15}$ iso- and anteiso- fatty acids, which are bacterial fatty acid methyl esters (BAMEs), $\delta^{13} \mathrm{C}$ values were only obtained on one sample from within the LLGM, and are similar to $\mathrm{C}_{16}, \mathrm{C}_{18}$ and TOC $\delta^{13} \mathrm{C}$ values (Fig. 3c).

\subsubsection{Alkanols and sterols}

LZ1029 contains a suite of mainly even-numbered $n$ alkanols from $C_{22}$ to $C_{28}$, as well as the odd numbered $C_{21}$ $n$-alkanol. The $\mathrm{C}_{24} n$-alkanol is most abundant throughout most of the core. Total $n$-alkanol concentrations range from
$4.7 \mathrm{ng} \mathrm{g}^{-1}$ TLE at $12 \mathrm{ka}$ to $15.6 \mathrm{ng} \mathrm{g}^{-1}$ TLE at $6.5 \mathrm{ka}$, peaking at $13.6 \mathrm{ng} \mathrm{g}^{-1}$ TLE during the LLGM (Fig. 2c). Similar to total $n$-alkanoic acid concentrations, total $n$-alkanols begin to increase at approximately $38 \mathrm{ka}$ with a peak in abundance during the LLGM. It is notable that the $\mathrm{C}_{21} n$-alkanol is present throughout the core, reaching peak abundance (26 ka) at $3.9 \mathrm{ng} \mathrm{g}^{-1}$ TLE, exceeded only by the $\mathrm{C}_{22} \mathrm{C}_{24}$ and $\mathrm{C}_{26} n$-alkanols. Typically $n$-alkanols demonstrate strong even over odd carbon-number predominance, thus the consistent and abundant presence of the $\mathrm{C}_{21} n$-alkanol is unusual. The source of odd carbon-numbered $n$-alkanols in lakes is unknown (e.g. Castañeda et al., 2011) and requires further investigation.

Sterols and stanols were detected in only one sample (21 ka) during the LLGM and are represented by cholestanol, $\beta$-sitosterol (Henderson et al., 1972), and dinosterol (Piretti et al., 1997). The triterpene isoarborinal is also present in sediments from the LLGM. The $\mathrm{C}_{30}$ and $\mathrm{C}_{32} 1,15 n$-alkyl diols are present during the LLGM, the $\mathrm{C}_{32}$ at relatively high concentrations ( $\left.4.6 \mathrm{ng} \mathrm{g}^{-1} \mathrm{TLE}\right)$, persisting between $38 \mathrm{ka}$ and $17 \mathrm{ka}$.

Isotopic values of $n$-alkanols are similar to, but more variable than, the mid- and long-chain FAMEs, with the $\mathrm{C}_{21}, \mathrm{C}_{22}$, and $\mathrm{C}_{24} n$-alkanols having lowest $\delta^{13} \mathrm{C}$ during the LLGM (see $\mathrm{C}_{21}$ and $\mathrm{C}_{24} n$-alkanols, Fig. $3 \mathrm{~d}$; other $n$-alkanols in Supplement). The $\mathrm{C}_{32} 1,15 n$-alkyl diol is isotopically similar to bulk $\delta^{13} \mathrm{C}$ values, remaining relatively constant through the LLGM (Fig. 3d).

\subsubsection{GDGTs}

Branched GDGTs (brGDGTs) were present in all samples in concentrations ranging from 5 to $112 \mu \mathrm{g} \mathrm{g}^{-1} \mathrm{TLE}$, with an average value of $40.9 \mathrm{\mu g} \mathrm{g}^{-1}$ TLE (Fig. 5c). The isoprenoid GDGT crenarchaeol was also present in generally lower concentrations ranging from 0.2 to $149 \mu \mathrm{g} \mathrm{g}^{-1}$ TLE, with an average value of $12.8 \mathrm{gg} \mathrm{g}^{-1}$ TLE (Fig. 5d). A maximum in crenarchaeol abundance is noted during the LLGM. The Branched and Isoprenoid Tetraether (BIT) index, based on relative abundances of branched GDGTs vs. the compound crenarchaeol, provides a proxy for aquatic vs. soil organic matter input (Hopmans et al., 2004). BIT values in Lake El'gygytgyn are generally high, indicating increased inputs of branched GDGTs relative to crenarchaeol, and range from 0.39 to 0.94 with the lowest values of the record noted during the LLGM (Fig. 5e).

\section{Discussion}

This study explores the changing sources of organic matter contributing to Lake El'gygytgyn during MIS 1-3, as well as possible geochemical connections to regional paleoclimate. Our discussion begins with the observation that molecular variability does not correspond directly with MIS intervals or 


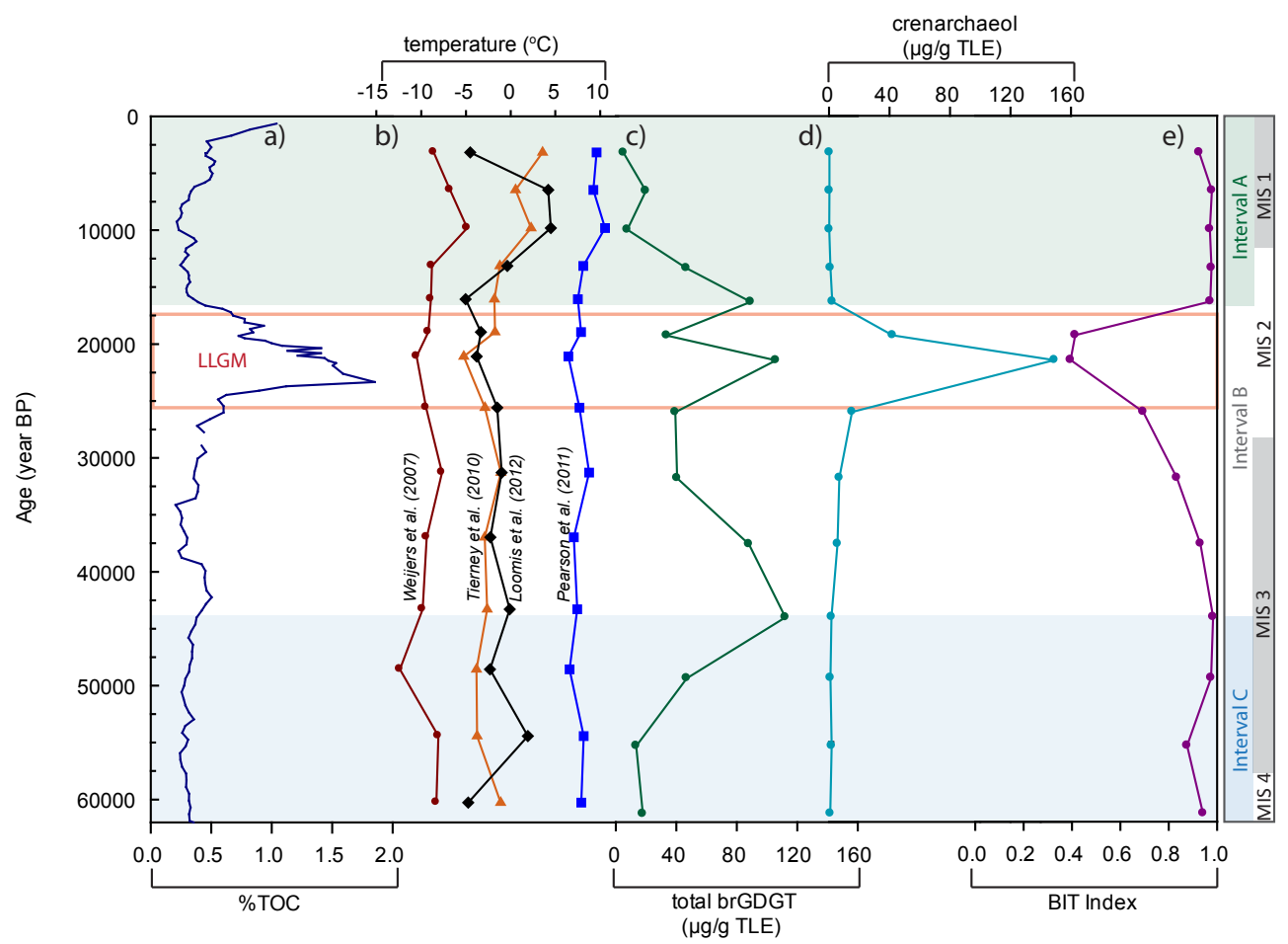

Fig. 5. Branched and isoprenoid GDGTs in Lake El'gygytgyn. The interval of the LLGM is highlighted. (a) \% TOC (Murdock et al., 2012), (b) MBT/CBT-derived temperatures applying the calibrations of Weijers et al. (2007; red circles), Tierney et al. (2010a; orange triangles), Loomis et al. (2012; black diamonds) and Pearson et al. (2011; blue squares). Note that the fractional abundance calibration of Tierney et al. (2010) and the stepwise forward selection calibration of Loomis et al. (2012) were applied. (c) Total branched GDGTs concentrations, (d) concentrations of the isoprenoid GDGT crenarchaeol, and (e) BIT index values. The orange box denotes LLGM.

variations in bulk geochemistry, but rather defines three time intervals of variability within the past $63 \mathrm{kyr}$. Next, sources of OM are explored, followed by a discussion of production vs. preservation of $\mathrm{OM}$ in the lake sediment. We then explore the negative shifts in bulk TOC $\delta^{13} \mathrm{C}$ values and discuss potential causes, as well as evidence for anoxia in the water column. Finally, our discussion ends by placing Lake El'gygytgyn in a paleoclimate context, noting the GDGT temperature record and other temperature reconstructions from Beringia.

\subsection{Division of LZ1029 record into intervals A, B, C}

Prior research (e.g. Melles et al., 2007; Minyuk et al., 2007; Nowaczyk et al., 2007) has argued that the magnetic susceptibility, inorganic geochemical, and biogeochemical records from Lake El'gygytgyn correspond well with Pleistocene marine isotope stages (MIS). This holds true for core LZ1029, in which changes in rock magnetic properties and \% TOC are synchronous with MIS boundaries (Murdock et al., 2012). However, close inspection of LZ1029 TOC $\delta^{13} \mathrm{C}$ values, molecular abundances, and isotopic compositions presented here suggests changes in OM sources and carbon cycling at Lake El'gygytgyn that precede, for example, the sharp increase in \% TOC at the start of MIS 2. As such, we divide our record into three intervals A, B and C (Figs. 2-4) based on molecular variability in $n$-alkanes, $n$-alkanoic acids, and $n$-alkanols. The boundaries between these intervals are approximate because of the low resolution of this record.

Compared to deeper sections of LZ1029, Interval A ( $17 \mathrm{ka}$ to present) is characterized by lower \%TOC, lower absolute concentrations of long-chain FAMEs, $n$-alkanols and $n$-alkanes, relatively greater abundance of long-chain $n$ alkanes and FAMEs, and relatively similar $\delta^{13} \mathrm{C}$ values for all measured FAMEs and for all $n$-alkanes. Tree and shrub pollen (Lozhkin et al., 2007) is relatively high during this interval. This interval includes MIS 1 and extends into MIS 2.

Interval $\mathrm{B}(\sim 42 \mathrm{ka}$ to $\sim 17 \mathrm{ka})$ is characterized by high absolute concentrations of $n$-alkanoic acids, $n$-alkanes and $n$ alkanols, as well as the only detectable quantities of sterols and methyl-branched fatty acids found in this study. The base of Interval B is defined by the increase in absolute FAME concentrations compared to those deeper in the core, and by the progressive ${ }^{13} \mathrm{C}$ depletion of $n$-alkanols and the $\mathrm{C}_{14}-\mathrm{C}_{28} n$-alkanoic acids paralleling TOC $\delta^{13} \mathrm{C}$ values. The $\mathrm{C}_{30} n$-alkanoic acid and $n$-alkanes show little to no negative shift in $\delta^{13} \mathrm{C}$ values during this interval. The uppermost portion of Interval B includes the LLGM, characterized by the most negative lipid $\delta^{13} \mathrm{C}$ values, the greatest absolute concentrations of $n$-alkanes, $n$-alkanols, FAMEs 
and crenarchaeol, relatively higher concentrations of shorterchain versus longer-chain $n$-alkanoic acids and $n$-alkanes, as well as the lowest calculated BIT index values. The changes in lipid abundance and isotopic composition observed throughout Interval B suggests that the LLGM is the terminal part of a broader time interval of environmental change in and around the lake that is not captured in the bulk \% TOC and $\mathrm{C} / \mathrm{N}$ records. The TOC peak may represent a change in the non-solvent extractable portion of the organic matter. Pollen during Interval B derives almost exclusively from herbaceous plants, mainly grasses (Lozhkin et al., 2007).

Interval $\mathrm{C}(\sim 63 \mathrm{ka}$ to $\sim 42 \mathrm{ka})$ is similar to Interval $\mathrm{A}$ in that it is characterized by lower \% TOC and relatively low concentrations of FAMEs, alkanols, and $n$-alkanes. Lipid $\delta^{13} \mathrm{C}$ values are similar to those found in Interval A, with no divergence in $\delta^{13} \mathrm{C}$ values between different $n$-alkanoic acids. However, short-chain FAMEs are relatively most abundant within this interval, and the pollen record suggests slightly lesser contributions from trees and shrubs compared to Interval A (Lozhkin et al., 2007).

\subsection{Sources of organic matter}

Bulk sedimentary geochemistry data from Lake El'gygytgyn pilot cores display synchronous shifts between glacial and interglacial intervals. In particular, increased TOC during the LLGM has been interpreted as a signal of increased preservation of organic matter during times of decreased oxygen in the water column due to interannual ice cover (Melles et al., 2007). Compound-specific analysis helps to separate the various sources contributing to the organic matter, and how these sources have changed through time. Our results indicate that sedimentary organic matter at Lake El'gygytgyn mostly falls into two source categories: terrestrial and aquatic, with only minor contributions from microbial sources.

Our results indicate that terrestrial $\mathrm{OM}$ is the main $\mathrm{OM}$ source to Lake El'gygytgyn throughout the past $\sim 60 \mathrm{kyr}$ (also noted in Wilkie, 2012), which is consistent with the continuous accumulation of pollen in Lake El'gygytgyn sediments throughout this record (Lozhkin et al., 2007) and similar to findings from other Siberian lakes (Ouellette, 2003; Rodgers, 2005). Terrestrially derived OM is represented by the suite of $n$-alkanes as well as the $\mathrm{C}_{30} n$-alkanoic acid, and is possibly suggested by the suite of branched GDGTs (see below for caution in assigning sources of GDGTs). This interpretation is strengthened by the nearly constant $\delta^{13} \mathrm{C}$ values of $n$-alkanes and the $\mathrm{C}_{30} n$-alkanoic acid through Intervals C, B and A (Fig. 3). A similar result has been noted for long-chain $n$-alkane $\delta^{13} \mathrm{C}$ values at Lake Baikal, which show little variability from the LGM through the Holocene (Brincat et al., 2000). These constant $\delta^{13} \mathrm{C}$ values require lipid synthesis from a carbon source that does not change in $\delta^{13} \mathrm{C}$ across this time interval, i.e. atmospheric $\mathrm{CO}_{2}$. The relatively high \% TOC and high lipid yield during the LLGM indicate that, surprisingly, the LLGM corresponds to the time of maximum terrestrial OM delivery to the sediments, possibly via ephemeral ice-free moats along the lake margin during full glacial summers and peak insolation, by intermittent streams carrying terrestrial organic matter from the basin, or by aeolian-blown sediment melting through the ice in summer (e.g. Lawson et al., 2004 and references therein). Interestingly, the $\mathrm{C}_{31}$ and $\mathrm{C}_{33} n$-alkanes achieve their peak concentrations well before the LLGM (38 ka), while maxima in other long-chain $n$-alkane concentrations are synchronous with the TOC maximum (Fig. 2d). These trends suggest changes in terrestrial $\mathrm{OM}$ and thus terrestrial ecology, and hint that the peak in TOC is derived from multiple sources to contributing increased organic carbon at different times. It remains unclear why, or how, terrestrial OM inputs can remain dominant throughout this time interval, including times such as the LLGM when the lake was perennially ice-covered, and when extremely cold and dry conditions should have limited terrestrial primary production on the landscape surrounding Lake El'gygytgyn. In comparison to other Arctic lakes (e.g., Fish Lake, Nunavut, Canada $\mathrm{Ng}$ and King, 2004; West Greenland - Perren et al., 2012; Dune Lake, Alaska - Finney et al., 2012), TOC concentrations are very low. Consequently, terrestrial inputs are significant only in that absolute concentrations consistently exceed aquatically sourced material, which may be explained by the ultra-oligotrophic nature of Lake El'gygytgyn and does not suggest that there is a large export from the terrestrial ecosystem to the lake.

Aquatic sources are secondary to terrestrially derived OM throughout the record, but are greatest during Interval B $(\sim 43 \mathrm{ka}$ to $\sim 17 \mathrm{ka})$ and specifically the LLGM. This is supported by the increase in the absolute abundance of $\mathrm{C}_{14}-\mathrm{C}_{22}$ FAMEs and $n$-alkanols, as well as the occurrence of sterols and diols during this interval. In addition to these commonly associated aquatic markers, there is evidence to suggest an additional aquatic source producing long-chain $n$-alkanoic acids and $n$-alkanols during Interval $\mathrm{B}$. The $\delta^{13} \mathrm{C}$ values of the $\mathrm{C}_{20}-\mathrm{C}_{22} n$-alkanoic acids show an approximately $8 \%$ o negative excursion during Interval $\mathrm{B}$ (see $\mathrm{C}_{20} n$-alkanoic acid, Fig. 3c), indicating a similar negative shift in the $\delta^{13} \mathrm{C}$ value of the inorganic carbon source supporting aquatic primary production. During this time, the $\mathrm{C}_{24}, \mathrm{C}_{26}$ and $\mathrm{C}_{28}$ $n$-alkanoic acids show an approximately $4 \%$ negative excursion, while the $\delta^{13} \mathrm{C}$ values of the $\mathrm{C}_{30} n$-alkanoic acid remain nearly constant (see $\mathrm{C}_{26}$ and $\mathrm{C}_{30} n$-alkanoic acids, Fig. 3c). Thus, the $\delta^{13} \mathrm{C}$ values of the $\mathrm{C}_{24}-\mathrm{C}_{28} n$-alkanoic acids can be interpreted as roughly equal contributions from a terrestrial source with a nearly constant $\delta^{13} \mathrm{C}$ value and from an aquatic source (that experiences an approximately $8 \%$ o negative excursion during Interval B). This occurrence is consistent with other literature confirming numerous (if infrequent) microalgal and bacterial sources of long-chain $n$ alkanoic acids (Bobbie and White, 1980; Logan and Eglinton, 1994; Schouten et al., 1998; Volkman et al., 1980). It is 
not clear if this aquatic source for the $\mathrm{C}_{24}-\mathrm{C}_{28}$ FAMEs persists throughout the LZ1029 record, with a $\delta^{13} \mathrm{C}$ value for this source shifting through time, or if it is confined to Interval $\mathrm{B}$, when changes in lake ecology may be accompanied by $\mathrm{C}_{24}-\mathrm{C}_{28} n$-alkanoic acid-producing aquatic organisms; both scenarios are supported by available data. Thus, our results corroborate the aforementioned studies in demonstrating that caution must be applied when assigning sources of longchain FAMEs in sediments, and it should not be assumed that these compounds derive mainly from terrestrial sources. Similar caution must be applied in interpreting the source of $n$-alkanols. Our results show a substantial (10-15\%o) negative excursion in $\mathrm{C}_{22}-\mathrm{C}_{28} n$-alkanol $\delta^{13} \mathrm{C}$ values during Interval $\mathrm{B}$ (see $\mathrm{C}_{24}$ and $\mathrm{C}_{28} n$-alkanols, Fig. $3 \mathrm{~d}$ ); while these $n$-alkanols are commonly assigned a terrestrial source, the negative excursion in $\delta^{13} \mathrm{C}$ values requires an aquatic contribution at least during Interval $\mathrm{B}$. Additionally, the approximately $3 \%$ negative excursion in the $\mathrm{C}_{25} n$-alkane $\delta^{13} \mathrm{C}$ values indicate that this compound may partly have an aquatic source such as aquatic macrophytes (Ficken et al., 2000), at least during the LLGM.

Microbially derived OM is not an abundant source of OM in Lake El'gygytgyn sediments. Two fatty acids diagnostic of bacteria, $\mathrm{C}_{15}$ iso- and $\mathrm{C}_{15}$ anteiso- FAMEs (Kaneda, 1991), were present at low concentrations during the LLGM (21 ka). Markers of microbial methane cycling, such as diplopterol and hydroxyarchaeol, were not detected. The compound crenarchaeol, produced by marine and lacustrine Thaumarchaeota (Pitcher et al., 2011 and references therein), was detected at low concentrations throughout most of the record, with exception of the LLGM.

In marine environments, the BIT index provides a proxy for aquatic versus soil organic matter input to sediments (Hopmans et al., 2004). Branched GDGTs are thought to be produced by anaerobic soil bacteria (Weijers et al., 2007), possibly Acidobacteria (Sinninghe Damsté et al., 2011), which are commonly found in soils and peats, but the source organism(s) presently remains unknown. BIT values range from 0 to 1; a value of 0 indicates a purely aquatic source while a value of 1 represents source from soil organic matter (Hopmans et al., 2004). However, use of the BIT index in lacustrine systems is not straightforward, as it appears that branched GDGTs are produced in situ in the water columns of many lakes (e.g. Tierney et al., 2012; Sinninghe Damsté et al., 2009; Tierney et al., 2010a; Tierney and Russell, 2009; Zink et al., 2010; Blaga et al., 2009; Bechtel et al., 2010). Furthermore, several studies have noted that changes in the BIT index can be mainly driven by changes in crenarchaeol concentrations (Castañeda and Schouten, 2011 and references therein). This is the case at Lake El'gygytgyn, which is generally characterized by high BIT values of 0.9 to 1 , but lower BIT values of around 0.4 are noted during the LLGM (Fig. 5e). This drop in the BIT index during the LLGM is driven by a significant increase in the concentration of crenarchaeol but concentrations of branched GDGTs also in- crease at this time (Fig. 5c). Overall, high BIT values and generally higher concentrations of branched GDGTs relative to crenarchaeol (with the exception of the interval around the LLGM) could be interpreted as indicating mainly terrestrial inputs to Lake El'gygytgyn. This scenario is feasible since peat exists within the watershed of the lake and since other terrestrial biomarkers are relatively abundant while aquatic biomarkers, such as those of primary producers, are generally absent in this oligotrophic lake. However, the possibility that branched GDGTs could be produced in situ, in the water column of Lake El'gygytgyn, is also a likely possibility, especially given the evidence for in situ production of branched GDGTs in many lakes. Further investigations are required to address this issue. Although it is unknown if the main source of branched GDGTs to Lake El'gygytgyn is from within the lake or within the watershed, relative temperature changes revealed by the MBT/CBT index (Weijers et al., 2007) provide insights into past climate variability in Beringia (see Sect. 4.6).

\subsection{Production vs. preservation of organic matter}

Bulk geochemical investigations from previous studies (e.g. Melles et al., 2007) suggested that high TOC during the LLGM is a function of increased preservation of organic matter (rather than increased production) due to a lack of oxygen during times of perennial lake ice cover. Values for the carbon to nitrogen ratio $(\mathrm{C} / \mathrm{N})$ from adjacent core PG1351 increase during the LLGM, suggesting either an increase in terrestrial input or, more likely, severe nitrogen limitation due to ice cover and stratification (Melles et al., 2007), as supported by bulk $\delta^{15} \mathrm{~N}$ results in this study (see Sect. 4.5).

Biomarker concentration results from this study support increased LLGM preservation of organic matter overall, but may also support increased aquatic productivity. Increased absolute concentrations of terrestrial organic matter and highest TLE/TOC values during the LLGM are more likely caused by increased preservation than increased terrestrial export productivity from a frozen landscape to an ice-covered lake. Terrigenous/aquatic ratios $\left(\mathrm{C}_{30} / \mathrm{C}_{20}\right.$ FAMEs $)$ display a decrease during the LLGM, suggesting an increase in aquatic contribution (Fig. 2g) and indicating that increased production of aquatic OM may also play a role during the LLGM. Higher aquatic productivity during the LLGM is also supported by diatom analysis (Snyder et al., 2012). A more gradual increase in TLE-normalized concentrations of all compound classes from both terrestrial and aquatic sources $(n-$ alkanes, $n$-alkanols, and FAMEs) during Interval B ( $\sim 3 \mathrm{ka}$ to $\sim 17 \mathrm{ka}$ ) prior to the LLGM suggests that oxygen in the water column did not disappear suddenly, as is evoked by the sudden and sharp TOC transition, but gradually weakens over the course of Interval B (Fig. 2). The magnitude and timing of the TOC peak at the LLGM must largely reflect preservation of additional organic matter other than the compounds evaluated in this study. This occurrence may reflect a 
threshold of dissolved oxygen, below which a much greater proportion of the organic matter in the lake is preserved. Alternatively, the sharp TOC peak may represent the progression of the oxycline above the sediment-water interface, thus exposing a portion of the water column to anoxic processes.

\subsection{What source(s) drive the negative shifts in TOC $\delta^{13} \mathrm{C}$ ?}

Negative shifts in TOC $\delta^{13} \mathrm{C}$ values during the LLGM in Lake El'gygytgyn sediments suggest that a highly depleted aquatic carbon end member (isotopic composition unknown) exists that is not present or abundant during warmer periods. The resulting TOC $\delta^{13} \mathrm{C}$ signature is a mixture between this highly depleted lacustrine $\mathrm{OM}$ and some contribution of relatively enriched terrestrial OM. The considerable LLGM ${ }^{13} \mathrm{C}$ depletion in $\mathrm{OM}$ at Lake El'gygytgyn differs from nearby Lake Elikchan (latitude $60^{\circ} 45^{\prime} \mathrm{N}$ ), which experiences glacial ${ }^{13} \mathrm{C}$-enrichment (Rodgers, 2005). Similarly, at Lake Baikal, glacial ${ }^{13} \mathrm{C}$ enrichment of bulk OM is observed (Brincat et al., 2000). These differences might be explained by the latitude difference, duration of ice cover, and access to atmospheric $\mathrm{CO}_{2}$ (Lozhkin and Anderson, 2011). Over the period of time covered in this study, the isotopic composition of terrestrial OM inputs does not change significantly (Köhler et al., 2010; Smith et al., 1999), as supported by the isotopic trend of the $\mathrm{C}_{30} n$-alkanoic acid (Fig. 3c). Therefore, it is assumed that changes in TOC $\delta^{13} \mathrm{C}$ reflect changes in the isotopic composition of aquatic organic matter and/or the changing ratio between aquatic and terrestrial carbon sources. At first glance, a possible contribution to a depleted TOC $\delta^{13} \mathrm{C}$ signature could be methane oxidation in the upper water column, which would require depleted oxygen in a portion of the water column. However, previous studies have postulated that due to the existence of an established community of non-migrating salmonid species (Nolan and BrighamGrette, 2007) and the persistence of vivianite from fish bones (Minyuk et al., 2007), it is likely that the upper water column has remained oxygenated through several glacial/interglacial cycles.

The original hypothesis driving this study proposed that methanogenic archaea and methanotrophic bacteria would become abundant during periods of near permanent ice cover, and that compounds diagnostic of these organisms would display extremely low $\delta^{13} \mathrm{C}$ values, suggesting methane cycling associated with water column anoxia. The largest contribution of depleted ${ }^{13} \mathrm{C}$ at Lake El'gygytgyn was expected to derive from extreme depletion (near -60\%o) in BAMEs diagnostic of bacterial sources within the short-chain fatty acids, which would indicate that bacteria in the lake were associated with methane cycling (Whiticar, 1999). However, methylbranched BAMEs ( $\mathrm{C}_{15}$ iso- and $\mathrm{C}_{15}$ ante iso-) were identified at sufficient concentrations to measure $\delta^{13} \mathrm{C}$ in only one LLGM sample $(21 \mathrm{ka})$, but displayed isotopic values similar to bulk $\delta^{13} \mathrm{C}(-33.0 \%$ to $-33.7 \%$; Fig. 3c). These results suggest a limited contribution from bacteria as an $\mathrm{OM}$ source, and that microbial biomass is not mainly derived from methane cycling processes.

The most isotopically depleted compounds at Lake El'gygytgyn were found within the mid-chain $n$-alkanoic acids $\left(\mathrm{C}_{20}\right.$ and $\left.\mathrm{C}_{22}\right)$, which are usually associated with aquatic organisms and vegetation (Meyers and Ishiwatari, 1993), submerged/emergent macrophytes, or bacteria. The mid-chain $n$-alkanoic acid $\sim 10 \%$ o carbon isotope excursion during Interval $\mathrm{B}\left(\sim 43 \mathrm{ka}\right.$ to $\sim 17 \mathrm{ka}$ ) (see $\mathrm{C}_{20}$, Fig. $3 \mathrm{c}$ ) suggests that aquatic organic matter was utilizing a pool of ${ }^{13} \mathrm{C}$-depleted $\mathrm{CO}_{2}$ in the water column that was not fully mixed with atmospheric $\mathrm{CO}_{2}$. There are several isotopically distinct sources of $\mathrm{CO}_{2}$ in this lake available to aquatic organisms: dissolved atmospheric $\mathrm{CO}_{2}$, oxidation of sinking degraded aquatic organic matter, dissolved inorganic carbon (DIC) from stream input, oxidation of dissolved or particulate organic carbon (DOC/POC) from stream input, or $\mathrm{CO}_{2}$ from oxidation of methane (Meyers, 1997; Whiticar, 1999). During the LLGM, the depletion of aquatic lipids to $-43.2 \%$ o (e.g. $\mathrm{C}_{20}$ FAME) suggests that these compounds derived in part from $\mathrm{CO}_{2}$ from oxidized $\mathrm{OM}$, either aquatic, terrestrial or methane, because only these $\mathrm{CO}_{2}$ sources could drive the negative lipid $\delta^{13} \mathrm{C}$ signatures. With no molecular evidence for methanogenesis, a likely scenario for generating depleted aquatic lipid ${ }^{13} \mathrm{C}$ is that aquatic primary producers were largely using recycled ${ }^{13} \mathrm{C}$-depleted $\mathrm{CO}_{2}$ from degradation and oxidation of sinking organic matter rather than atmospheric $\mathrm{CO}_{2}$.

This can be estimated using a simple isotope mass balance model. Assuming that atmospheric $\mathrm{CO}_{2} \delta^{13} \mathrm{C}$ values have remained nearly constant at $-6.5 \%$ o throughout the time interval of our record (Schmitt et al., 2012; Elsig et al., 2009), the $\Delta \delta^{13} \mathrm{C}$ between this $\delta^{13} \mathrm{C}_{\mathrm{CO} 2}$ and the post-LLGM $\mathrm{C}_{20}$ $n$-alkanoic acid suggests a fractionation $\left(\Delta \delta^{13} \mathrm{C}_{\mathrm{CO} 2-\mathrm{C} 20 \mathrm{FA}}\right)$ of $26.5 \%$. Using this fractionation and the $\delta^{13} \mathrm{C}$ value of $\mathrm{C}_{20}$ during the LLGM $(-43 \%$ ) allows us to estimate the $\delta^{13} \mathrm{C}$ value of $\mathrm{CO}_{2}$ in lake water during the LLGM $\left(-16.5 \% o=-43 \%\right.$ o $26.5 \%$ ) . Lake water-dissolved $\mathrm{CO}_{2}$ $\delta^{13} \mathrm{C}$ values of $-16.5 \%$ o can be achieved by a mixture of atmospheric $\mathrm{CO}_{2}\left(\delta^{13} \mathrm{C}=-6.5 \%\right)$ and $\mathrm{CO}_{2}$ from oxidized OM (TOC $\delta^{13} \mathrm{C}=-32 \%$ o during the LLGM); the isotope mass balance calculation suggests that $60.8 \%$ of $\mathrm{CO}_{2}$ in the lake during the LLGM is from the atmosphere while $39.2 \%$ is from oxidized OM.

Results show another notable characteristic, as explained in Sect. 4.2, in that some of the long-chain $n$-alkanoic acids $\left(\mathrm{C}_{24}, \mathrm{C}_{26}, \mathrm{C}_{28}\right)$ expected to derive from terrestrial sources demonstrate a $\sim 5 \%$ o depletion during Interval B $(\sim 43 \mathrm{ka}$ to $\sim 17 \mathrm{ka}$ ) similar to aquatic lipids. This additional aquatic contribution certainly influences the negative shift in TOC $\delta^{13} \mathrm{C}$ during Interval $\mathrm{B}$. 


\subsection{Is there biogeochemical evidence for anoxia?}

Previous studies (Melles et al., 2007; Nowaczyk et al., 2007) have posited that extremely low magnetic susceptibility values, as well as finely laminated sediments, support evidence for extreme water column anoxia during periods of interpreted glacial conditions. However, it cannot be determined from this evidence whether anoxia exists in the water column or strictly in the sediments. To explore another possible indicator for anoxia, and to investigate the original interpretation that magnetic susceptibility is a proxy for lake ice cover due to dissolution of magnetite grains under highly anoxic conditions, this study attempted to link the magnetic susceptibility record to the nitrogen cycle through bulk $\delta^{15} \mathrm{~N}_{\text {total }}$ to show evidence of anoxia through denitrification. However, the expected bulk $\delta^{15} \mathrm{~N}$ enrichment (denitrification) signal is not evident during the LLGM. Furthermore, bulk $\delta^{15} \mathrm{~N}$ actually appears to be anti-correlated with TOC during the LLGM (Fig. 4). There is perhaps an initial pulse of denitrification in response to anoxia at the beginning of Interval B ( $\sim 43 \mathrm{ka}$ to $\sim 17 \mathrm{ka})$, but this trend deteriorates resulting in relative ${ }^{15} \mathrm{~N}$-depletion during the LLGM, possibly related to ultra-oligotrophic conditions and a limitation of available nitrate in the lake and the surrounding frozen landscape. Other evidence for anoxia might be found in the biomarker record with compounds that are often associated with anoxic conditions or methanogenesis such as tetrahymanol, loliolide/isololiolide, archaeol, sn2-hydroxyarchaeol, crocetane, and 2,6,10,15,19-pentamethylicosane. None of the above compounds were identified in this study.

Several outstanding questions remain: how intense is water column anoxia? And, where is the oxycline? The results presented here could be compatible with a thin anoxic layer just above the sediment water interface, though it appears unlikely that a severe and significant anoxic layer throughout the water column persisted during the LLGM. Water column anoxia may not be an "on/off" switch, as the sudden shifts of magnetic susceptibility and TOC suggest, but a slow process that impedes degradation of organic matter (as shown by increased lipid concentrations relative to TOC) even before the sharp spike in TOC is apparent. Suboxic conditions may trigger methane cycling until limited by labile carbon, and followed by iron reduction, though more research is needed on this topic.

\subsection{Paleoclimate of Beringia during the last $60 \mathrm{kyr}$}

\subsubsection{Primary production during the LLGM}

Lake El'gygytgyn is an unusual lake in that the sediment record for at least the past $200 \mathrm{kyr}$ is characterized by higher TOC (Melles et al., 2007; Murdock et al., 2012) and biomarker concentrations during glacial periods. In contrast, other lakes, including Lake Baikal (Prokopenko and Williams, 2004), exhibit high TOC during interglacial pe- riods, reflecting higher production during warmer climate intervals. Interestingly, the interval studied here (MIS 1-3) differs from earlier sections of the El'gygytgyn record as D'Anjou et al. (2012) note that from MIS 9-12, increased concentrations of all biomarkers occur during the interglacial periods rather than during the glacials. Thus, MIS 2 (the LLGM) may be somewhat anomalous in comparison to earlier glacials. The increased TOC at Lake El'gygytgyn during the LLGM may result from increased primary productivity (Snyder et al., 2012), increased OM preservation, decreased dilution of TOC from inorganic inputs, or some combination of these factors.

The interval of elevated TOC concentrations at Lake El'gygytgyn is characterized by negative excursions in TOC $\delta^{13} \mathrm{C}$ values (Fig. 3) and increased OM C/N ratios (Melles et al., 2007). This may reflect an increase in the delivery and burial of terrestrially derived OM during glaciation as terrestrial $\mathrm{OM}$ is characterized by higher $\mathrm{C} / \mathrm{N}$ ratios and lower $\delta^{13} \mathrm{C}$ values than typical aquatic primary production. This scenario is supported by the continuous record of pollen deposition in Lake El'gygytgyn sediments (Lozhkin et al., 2007), indicating production and delivery of terrestrial OM from the landscape during both glacial and interglacial intervals. Previous studies of perennially ice-covered lakes have shown that as aeolian sediments accumulate on the surface, they are warmed in the summer and can be melted into and through the ice (Lawson et al., 2004 and references therein), which may explain the continuous supply of terrestrial OM to Lake El'gygytgyn during glacial intervals.

The diatom record of Lake El'gygytgyn offers insights into past primary production during both glacial and interglacial periods and reveals a number of intervals of exceptionally high diatom concentration, which correspond to periods of warm climate including MIS 11 and MIS 31 (Snyder et al., 2012). However, temperature is not the only factor controlling primary production at Lake El'gygytgyn, as a number of cold but highly productive intervals are also noted during the past $200 \mathrm{kyr}$, including during MIS 2 (Snyder et al., 2012). The high \% TOC in Lake El'gygytgyn sediments noted during the LLGM coincides with high biogenic silica values (20-35\%), which exceed Holocene values, and the diatom assemblage at $20-25 \mathrm{ka}$ indicates a higher nutrient status compared to the Holocene (Snyder et al., 2012). These cold productive intervals likely reflect changes in lake circulation, by either occasional circulation of an ice-covered lake or by circulation-induced seasonal nutrient pulses under transparent ice cover, which could cause the high contributions of nutrient-favoring diatoms during the LLGM (Snyder et al., 2012). Such a scenario could also account for the increased \% TOC and the negative excursion in TOC $\delta^{13} \mathrm{C}$ values, as increased nutrient supply to an ice-covered lake could simulate primary productivity, resulting in increased recycling of the internal carbon pool. 


\subsubsection{Temperature change in Beringia}

A number of techniques have been used to examine the temperature history of Beringia, including fossil pollen, chironomid and beetle assemblages (Miller et al., 2010). Here, we apply the MBT/CBT Index based on branched GDGTs, which provides a method for reconstructing mean annual soil temperature (Weijers et al., 2007). An ample amount of evidence exists that branched GDGTs are also produced in situ in lakes (see Sect. 4.2) and thus the proxy has been used to reconstruct lake water temperature (e.g. Sinninghe Damsté et al., 2012; Loomis et al., 2012). An increasing number of studies have provided calibrations of MBT/CBT paleothermometer to lake temperature (e.g. Pearson et al., 2011; Sun et al., 2011; Tierney et al., 2010a; Zink et al., 2010; Loomis et al., 2012). Applying these calibrations to Lake El'gygytgyn sediments yields a wide variety of reconstructed temperatures. For example, the global soils calibration of Weijers et al. (2007) yields temperatures ranging from -12.4 to $-4.9^{\circ} \mathrm{C}$, whereas applying the lakes calibrations of Pearson et al. (2011), Sun et al. (2011), Loomis et al. (2012) and Tierney et al. (2010a) yields temperatures ranging from 6.6 to $10.6^{\circ} \mathrm{C}, 2.0$ to $7.6^{\circ} \mathrm{C},-5.0$ to $4.5^{\circ} \mathrm{C}$, and -5.2 to $3.5^{\circ} \mathrm{C}$, respectively (Fig. $5 \mathrm{~b}$ ). Modern air temperatures at Lake El'gygytgyn range from $-40^{\circ} \mathrm{C}$ in winter to $+26^{\circ} \mathrm{C}$ in summer with a mean annual temperature of $-10.3^{\circ} \mathrm{C}$, while the temperature of the water column ranges from 0 to $4{ }^{\circ} \mathrm{C}$ (Nolan and Brigham-Grette, 2007). Given the wide variability in modern temperatures at Lake El'gygytgyn, it is not clear which of the available MBT/CBT calibrations, if any, is the most appropriate to apply, especially if a seasonal bias in branched GDGT production exists. Due to the current lack of a modern calibration study at Lake El'gygytgyn, we note that absolute temperatures reconstructed by the MBT/CBT proxy, in addition to the overall amplitude of temperature shifts, cannot be trusted; however, the data can be interpreted in terms of relative changes in MBT/CBT data (warming and cooling) (also see D'Anjou et al., 2012). It has been noted that site-specific temperature calibrations are likely required when applying GDGT-based temperature proxies to lakes (Castañeda and Schouten, 2011) and thus a modern study of Lake El'gygytgyn and its watershed is required to determine where the branched GDGTs are produced and if MBT/CBT based MAATs represents the annual mean temperature or a rather a seasonal temperature. Despite limitations associated with reconstructing absolute temperature, we find that relative MBT/CBT-derived temperatures from Lake El'gygytgyn are in agreement with other temperature reconstructions from Beringia highlighting the promise of this technique for generating Arctic terrestrial paleotemperature records.

The major features noted in the MBT/CBT record are, (1) variable temperatures throughout MIS 3 including intervals that are both warmer and cooler than the LLGM, (2) relatively cool temperatures during the LLGM in comparison to the Holocene, and, (3) an early Holocene thermal max- imum. The relative trends MBT/CBT-derived temperatures are in good agreement with the diatom $\delta^{18} \mathrm{O}$ record from nearby core LZ1024, which reveals two temperature maxima within MIS 3 at $34.3 \mathrm{ka}$ and $54.6 \mathrm{ka}$, bounding a relatively cold interval (Chapligin et al., 2012). In the lower resolution MBT/CBT record of LZ1029, temperature maxima within MIS 3 are noted at approximately 31.8 and $55.3 \mathrm{ka}$, when temperatures slightly exceed those of the late Holocene, while the lowest temperature of the entire record is noted at approximately $49.4 \mathrm{ka}$. Previous reconstructions of MIS 3 climate have revealed variable conditions across Beringia (e.g. Lozhkin and Anderson, 2011). In the Laptev Sea region (Arctic Siberia) numerous paleoecological proxies (pollen, insect fossils, rhizopods, ostracods) suggests a regional Middle Weichselian climatic optimum at 40-32 ka (Andreev et al., 2011 and references therein; Lozhkin and Anderson, 2011 and references therein). Within the region of Western Beringia, variable conditions characterize MIS 3 with stable climate and vegetation noted northern areas. In contrast, southeastern areas of Western Beringia experienced a thermal maximum during mid-MIS 3, with conditions as warm or warmer than at present (Lozhkin and Anderson, 2011; Miller et al., 2010). At nearby Lake Elikchan, there is evidence for several intervals within MIS 3 when summer temperatures were similar to the Holocene (Anderson and Lozhkin, 2001), with the warmest interval occurring from 44-35 ka. In central and eastern Beringia (Alaska and the Yukon Territory) fossil beetle assemblages reveal a warming from 35-30 ka from northern and western sites, while interior sites exhibit a less pronounced warming (Elias, 2000). Overall, during MIS 3 eastern Beringia appears to have been characterized a harsher climate than at present (Miller et al., 2010).

The Lake El'gygytgyn MBT/CBT record reveals relatively cooler temperatures during the LLGM, although conditions were not as severe as during the cold interval of MIS 3 (Fig. 5). In contrast, the Lake El'gygytgyn diatom $\delta^{18} \mathrm{O}$ record, which is interpreted as reflecting mainly changes in air temperature, displays the most depleted values during the LLGM ( $\sim 24 \mathrm{ka})$ suggesting it was the coldest interval of the past $60 \mathrm{kyr}$ (Chapligin et al., 2012). Pollen-based climate reconstructions from Lake El'gygytgyn suggest the LLGM was characterized by approximately $4{ }^{\circ} \mathrm{C}$ cooler summer air temperatures and reduced precipitation in comparison to the modern (Melles et al., 2012). Based on inorganic geochemistry and sediment facies, Melles et al. (2007) suggested that MIS 2 was cold and dry and that Lake El'gygytgyn possessed a stratified water column with significant primary production occurring below the ice. Although we did not find any conclusive biomarker evidence for water column anoxia, we also cannot rule out this possibility, and our results support increased production of aquatic organic during the LLGM. Elsewhere throughout Beringia, and globally, a substantial amount of evidence exists for MIS 2 (LGM) cooling. In the Laptev Sea region paleoecological evidence indicates 
very cold and dry summers (Andreev et al., 2011). Eastern Beringia was also characterized by a cold and dry LGM with a notable west to east climate gradient in Alaska and the Yukon Territory (Kurek et al., 2009 and references therein). Here, conditions were more severe in interior regions. Temperature reconstructions based on beetle assemblages indicate maximum temperatures during the LGM were around 2$2.5^{\circ} \mathrm{C}$ cooler than present in Arctic Beringia and $4{ }^{\circ} \mathrm{C}$ cooler at interior sites (Elias, 2000).

Following the LLGM, the MBT/CBT record indicates warming at Lake El'gygytgyn with the highest temperatures of the entire record noted at $\sim 10 \mathrm{ka}$ (Fig. 5). Pollen data from Lake El'gygytgyn suggest temperatures were $\sim 2$ to $4{ }^{\circ} \mathrm{C}$ warmer during the Holocene Thermal Maximum (HTM) than today (Lozhkin et al., 2007) and the diatom $\delta^{18} \mathrm{O}$ record of LZ1024 indicates enriched values at $8.9 \mathrm{ka}$ (Chapligin et al., 2012). Neither the Lake El'gygytgyn diatom $\delta^{18} \mathrm{O}$ record or the MBT/CBT record capture the Bølling-Allerød warming or the Younger Dryas cooling, both of which are well defined in the pollen record (Melles et al., 2012), likely due to the low sampling resolution of these records throughout this interval. In the Laptev Sea region early Holocene temperatures of up to $4{ }^{\circ} \mathrm{C}$ warmer than present are noted (Andreev et al., 2011 and references therein), similar in magnitude to the warming noted at Lake El'gygytgyn (Lozhkin et al., 2007). The HTM has been noted in numerous climate records from Beringia and elsewhere throughout the Arctic, attributed to a precession-driven increase in solar insolation (Kaufman et al., 2004; Miller et al., 2010). Following maximum warmth during the HTM, the MBT/CBT record reveals cooling towards the present. Similarly, diatom $\delta^{18} \mathrm{O}$ record suggests a shift towards cooler conditions following the HTM and exhibits more depleted values (Chapligin et al., 2012), while a slight decrease in pollen-reconstructed summer temperature is noted (Melles et al., 2012).

\section{Conclusions}

This work both assists in a greater understanding of the biogeochemical cycles occurring within Lake El'gygytgyn throughout various climate modes and expands on the body of compound-specific isotopic analysis in lake systems. Overall, we note several key findings:

1. Organic geochemical anoxic indicators are not present in Lake El'gygytgyn sediments during glacial periods, a finding that may support an interpretation of recycled carbon in an environment with reduced access to atmospheric carbon dioxide.

2. Lipid abundances and isotopic trends do not strictly correspond with either MIS boundaries or the inferred regional LLGM. Instead, molecular concentration and isotopic shifts are gradual and precede sharp changes noted in bulk geochemistry.
3. Lake El'gygytgyn displays relatively high concentrations of both terrestrial- and aquatic-sourced biomarkers during Interval B $(\sim 43 \mathrm{ka}$ to $\sim 17 \mathrm{ka})$ and especially during the LLGM. This is unusual in comparison to other lakes and also contrasts with previous glacial periods at Lake El'gygytgyn. As suggested previously (Snyder et al., 2012), cold productive intervals within Lake El'gygytgyn may reflect changes in lake circulation, delivering increased nutrients to the water column.

4. Isotopic analysis $\left(\delta^{13} \mathrm{C}\right)$ of long-chain $\mathrm{C}_{24}, \mathrm{C}_{26}$, and $\mathrm{C}_{28}$ $n$-alkanoic acids revealed that these compounds are not solely of terrestrial origin at Lake El'gygytgyn. However, the $\mathrm{C}_{30} n$-alkanoic acid provides a reliable terrestrial biomarker.

5. As direct evidence of methanogenesis is lacking throughout the record of MIS 1-3, substantial depletion in aquatic lipids during the LLGM suggests considerable recycling of $\mathrm{CO}_{2}$ from degraded organic matter back to aquatic primary producers with limited atmospheric $\mathrm{CO}_{2}$ exchange. Continual cycling within this system could drive aquatic lipids to depleted values of $-43 \%$.

6. The MBT/CBT proxy reflects relative temperature changes at Lake El'gygytgyn and reveals both warm and cold intervals occurring within MIS 3, relatively cool temperatures during the LLGM and an early Holocene thermal maximum, in agreement with other temperature reconstructions of Beringia.

\section{Supplementary material related to this article is available online at: http://www.clim-past.net/9/243/2013/ cp-9-243-2013-supplement.pdf.}

Acknowledgements. Carbon isotope analysis for this work was made possible by Yale University's Earth System Center for Stable Isotopic Studies. We also thank Carrie Petrik for laboratory sample preparation and David Finkelstein for manuscript review. We thank B. Beckmann and two anonymous reviewers for insightful comments that improved this manuscript. Funding for this research was provided by the International Continental Scientific Drilling Program (ICDP), the US National Science Foundation (NSF), the German Federal Ministry of Education and Research (BMBF), Alfred Wegener Institute (AWI) and GeoForschungsZentrum Potsdam (GFZ), the Russian Academy of Sciences Far East Branch (RAS FEB), the Russian Foundation for Basic Research (RFBR), and the Austrian Federal Ministry of Science and Research (BMWF).

Edited by: M. Melles 


\section{References}

Anderson, P. M. and Lozhkin, V.: The Stage 3 interstadial complex (Karginskii/middle Wisconsinan interval) of Beringia: variations in paleoenvironments and implications for paleoclimatic interpretations, Quaternary Sci. Rev., 20, 93-125, 2001.

Andreev, A. A., Schirrmeister, L., Tarasov, P. E., Ganopolski, A., Brovkin, V., Siegert, C., Wetterich, S., and Hubberten, H. W.: Vegetation and climate history in the Laptev Sea region (Arctic Siberia) during Late Quaternary inferred from pollen records, Quaternary Sci. Rev., 30, 2182-2199, 2011.

Bechtel, A., Smittenberg, R. H., Bernasconi, S. M., and Schubert, C. J.: Distribution of branched and isoprenoid tetraether lipids in an oligotrophic and a eutrophic Swiss lake: insights into sources and GDGT-based proxies, Org. Geochem., 41, 822-832, 2010.

Berger, A. and Loutre, M. F.: Insolation values for the climate of the last 10 million years, Quaternary Sci. Rev., 10, 297-317, 1991.

Blaga, C. I., Reichart, G. J., Heiri, O., and Sinninghe Damsté, J. S.: Tetraether membrane lipid distributions in water-column particulate matter and sediments: a study of 47 European lakes along a northesouth transect, J. Paleolimnol., 41, 523-540, 2009.

Bobbie, R. J. and White, D. C.: Characterization of benthic microbial community structure by high-resolution gas chromatography of Fatty Acid methyl esters, Appl. Environ. Microbiol., 39, 12121222, 1980.

Boon, J. J., Rijpstra, W. I. C., de Lange, F., de Leeuw, J. W., Yoshioka, M., and Shimizu, Y.: Black sea sterol- a molecular fossil for dinoflagellate blooms, Nature, 277, 125-127, 1979.

Brigham-Grette, J., Lozhkin, A. V., Anderson, P. M., and Glushkova, O.: Paleoenvironmental conditions in Western Beringia before and during the last glacial maximum, in: Entering America: Northeast Asia and Beringia before the last glacial maximum, edited by: Madsen, D., 29-61, University of Utah Press, 2004.

Brigham-Grette, J., Melles, M., and Minyuk, P.: Overview and significance of a $250 \mathrm{ka}$ paleoclimate record from El'gygytgyn Crater Lake, NE Russia, J. Paleolimnol., 37, 1-16, doi:10.1007/s10933-006-9017-6, 2007.

Brincat, D., Yamada, K., Ishiwatari, R., Uemura, H., and Naraoka, H.: Molecular-isotopic stratigraphy of long-chain n-alkanes in Lake Baikal Holocene and glacial age sediments, Org. Geochem., 31, 287-294, 2000.

Castañeda, I. S. and Schouten, S.: A review of molecular organic proxies for examining modern and ancient lacustrine envrionments, Quaternary Sci. Rev., 30, 2851-2891, 2011.

Castañeda, I. S., Werne, J. P., Johnson, T. C., and Powers, L. A.: Organic geochemical records from Lake Malawi (East Africa) of the last 700 years, part II: biomarker evidence for recent changes in primary productivity, Palaeogeogr. Palaeoclimatol., 303, 140154, 2011.

Chapligin, B., Meyer, H., Swann, G. E. A., Meyer-Jacob, C., and Hubberten, H.-W.: A 250 ka oxygen isotope record from diatoms at Lake El'gygytgyn, far east Russian Arctic, Clim. Past, 8, 1621-1636, doi:10.5194/cp-8-1621-2012, 2012.

Cranwell, P. A., Eglinton, G., and Robinson, N.: Lipids of aquatic organisms as potential contributors to lacustrine sediments.II, Org. Geochem., 11, 513-527, 1987.

D’Anjou, R. M., Wei, J. H., Castañeda, I. S., Brigham-Grette, J., Petsch, S. T., and Finkelstein, D. B.: High-latitude environmental change during MIS 8-12: biogeochemical evidence from Lake
El'gygytgyn, Far East Russia, Clim. Past Discuss., 8, 4745-4777, doi:10.5194/cpd-8-4745-2012, 2012.

Eglinton, G. and Hamilton, R. J.: Leaf Epicuticular Waxes, Science, 156, 1322-1335, 1967.

Elias, S. A.: Late Pleistocene climates of Beringia, based on analysis of fossil beetles, Quaternary Res., 53, 229-235, 2000.

Elsig, J., Schmitt, J., Leuenberger, D., Schneider, R., Eyer, M., Leuenberger, M., Joos, F., Fischer, H., and Stocker, T. F.: Stable isotope constraints on Holocene carbon cycle changes from an Antarctic ice core, Nature, 461, 507-510, 2009.

Forman, S. L., Pierson, J., Brigham-Grette, J., Nowaczyk, N. R., and Melles, M.: Luminescence geochronology for sediments from Lake El'gygytgyn, northeast Siberia, Russia: Constraining the timing of paleoenvironmental events for the past $200 \mathrm{ka}$, J. Paleolimnol., 37, 77-88, doi:10.1007/s10933-006-9024-7, 2007.

Ficken, K. J., Li, B., Swain, D. L., and Eglinton, G.: An $n$-alkane proxy for the sedimentary input of submerged/floating freshwater aquatic macrophytes, Org. Geochem., 31, 745-749, 2000.

Finney, B. P., Bigelow, N. H., Barber, V. A., and Edwards, M. E.: Holocene climate change and carbon cycling in a groundwaterfed, boreal forest lake: Dune Lake, Alaska, J. Paleolimnol., 48, 43-54, 2012

Frank, U., Nowaczyk, N. R., Minyuk, P., Vogel, H., Rosén, P., and Melles, M.: A $350 \mathrm{kyr}$ record of climate change from Lake El'gygytgyn, Far East Russian Arctic: refining the pattern of climate modes by means of cluster analysis, Clim. Past Discuss., 8 , 5109-5132, doi:10.5194/cpd-8-5109-2012, 2012.

Gebhardt, A. C., Niessen, F., and Kopsch, C.: Central ring structure identified in one of the world's best-preserved impact craters, Geology, 34, 145-148, doi:10.1130/G22278.1, 2006.

Giger, W., Schaffner, C., and Wakeham, S. G.: Aliphatic and olefinic hydrocarbons in recent sediments of Greifensee, Switzerland, Geochim. Cosmochim. Ac., 44, 119-129, 1980.

Henderson, W., Reed, W., and Steel, G.: The origin and incorporation of organic molecules in sediments as elucidated by studies of the sedimentary sequence from a residual Pleistocene lake, in: Advances in Organic Geochemistry, edited by: von Gaertner, $\mathrm{H}$ and Wehner, H., 335-352, Pergamon Press, 1972.

Hopmans, E. C., Schouten, S., Pancost, R. D., van der Meer, M. T. J., and Sinninghe Damsté, J. S.: Analysis of intact tetraether lipids in archaeal cell material and sediments by high performance liquid chromatography/atmospheric pressure chemical ionization mass spectrometry, Rapid Commun. Mass Spectrom., 14, 585-589, doi:10.1002/(SICI)10970231(20000415)14:7<585::AID-RCM913>3.3.CO;2-E, 2000.

Hopmans, E. C., Weijers, J. W. H., Schefuß, E., Herfort, L., Sinninghe Damsté, J. S., and Schouten, S.: A novel proxy for terrestrial organic matter in sediments based on branched and isoprenoid tetraether lipids, Earth Planet. Sci. Lett., 224, 107-116, doi:10.1016/j.eps1.2004.05.012, 2004.

Juschus, O., Preusser, F., Melles, M., and Radtke, U.: Applying SAR-IRSL methodology for dating fine-grained sediments from Lake El'gygytgyn, north-eastern Siberia, Quaternary Geochronol., 2, 187-194, doi:10.1016/j.quageo.2006.05.006, 2007.

Juschus, O., Melles, M., Gebhardt, a. C., and Niessen, F.: Late Quaternary mass movement events in Lake El'gygytgyn, North-eastern Siberia, Sedimentology, 56, 2155-2174, doi:10.1111/j.1365-3091.2009.01074.x, 2009. 
Kaneda, T.: Iso- and anteiso-fatty acids in bacteria: biosynthesis, function, and taxonomic significance, Microbiolog. Rev., 55, 288-302, 1991.

Kaufman, D. S., Ager, T. A., Anderson, N. J., Anderson, P. M., Andrews, J. T., Bartlein, P. J., Brubaker, L. B., Coats, L. L., Cwynar, L. C., Duvall, M. L., Dyke, A. S., Edwards, M. E., Eisner, W. R., Gajewski, K., Geirsdottir, A., Hu, F. S., Jennings, A. E., Kaplan, M. R., Kerwin, M. N., Lozhkin, A. V., MacDonald, G. M., Miller, G. H., Mock, C. J., Oswald, W. W., Otto-Bliesner, B. L., Porinchu, D. F., Ruhland, K., Smol, J. P., Steig, E. J., and Wolfe, B. B.: Holocene thermal maximum in the western Arctic (0-180 degrees W), Quaternary Sci. Rev., 23, 529-560, 2004.

Köhler, P., Fischer, H., and Schmitt, J.: Atmospheric $\delta^{13} \mathrm{CO}_{2}$ and its relation to $p \mathrm{CO}_{2}$ and deep ocean $\delta 13 \mathrm{C}$ during the late Pleistocene, Paleoceanography, 25, 1-16, doi:10.1029/2008PA001703, 2010.

Kurek, J., Cwynar, L. C., Ager, T. A., Abbott, M. B., and Edwards, M. E.: Late Quaternary paleoclimate of western Alaska inferred from fossil chironomids and its relation to vegetation histories, Quaternary Sci. Rev., 28, 799-811, 2009.

Lawson, J., Doran, P. T., Kenig, F., Des Marais, D. J., and Priscu, J. C.: Stable Carbon and Nitrogen Isotopic Composition of Benthic and Pelagic Organic Matter in Lakes of the McMurdo Dry Valleys, Antarctica, Aqua. Geochem., 10, 269-301, 2004.

Layer, P. W.: Argon-40/argon-39 age of the El'gygytgyn impact event, Chukotka, Russia, Meteor. Planet. Sci., 35, 591-599, 2000.

Logan, G. and Eglinton, G.: Biogeochemistry of the Miocene lacustrine deposit, at Clarkia, northern Idaho, USA, Org. Geochem., 21, 857-870, 1994.

Loomis, S. E., Russell, J. M., Ladd, B., Street-Perrott, A., and Sinninghe Damsté, J. S.: Calibration and application of the branched GDGT temperature proxy on East African lake sediments, Earth Planet. Sci. Lett., 357-358, 277-288, 2012.

Lozhkin, A. V. and Anderson, P. M.: Forest or no forest: implications of the vegetation record for climatic stability in Western Beringia during Oxygen Isotope Stage 3, Quaternary Sci. Rev., 30, 2160-2181, doi:10.1016/j.quascirev.2010.12.022, 2011.

Lozhkin, A. V., Anderson, P., Matrosova, T., and Minyuk, P.: The pollen record from El'gygytgyn Lake: implications for vegetation and climate histories of northern Chukotka since the late middle Pleistocene, J. Paleolimnol., 37, 135-153, doi:10.1007/s10933-006-9018-5, 2007.

Melles, M., Brigham-Grette, J., Glushkova, O., Minyuk, P., Nowaczyk, N. R., and Hubberten, H.-W.: Sedimentary geochemistry of core PG1351 from Lake El'gygytgyn - a sensitive record of climate variability in the East Siberian Arctic during the past three glacial - interglacial cycles, J. Paleolimnol., 37, 89-104, doi:10.1007/s10933-006-9025-6, 2007.

Melles, M., Brigham-Grette, J., Minyuk, P. S., Nowaczyk, N.R., Wennrich, V., DeConto, R. M., Anderson, P. M., Andreev, A. A., Coletti, A., Cook, T. L., Haltia-Hovi, E., Kukkonen, M., Lozhkin, A. V., Rosen, P., Tarasov, P., Vogel, H., and Wagner, B.: 2.8 Million Years of Arctic Climate Change from Lake El'gygytgyn, NE Russia, Science, 337, 315-320, 2012.

Meyers, P. A.: Organic geochemical proxies of paleoceanographic, paleolimnologic, and paleoclimatic processes, Science, 27, 213 250, 1997.
Meyers, P. A. and Ishiwatari, R.: Lacustrine organic geochemistryan overview of indicators of organic matter sources and diagenesis in lake sediments, Org. Geochem., 20, 867-900, 1993.

Miller, G., Brigham-Grette, J., Alley, R., Anderson, L., Bauch, H., Douglas, M., Edwards, M., Elias, S., Finney, B., Fitzpatrick, J., Funder, S., V, Herbert, T., Hinzman, L., Kaufman, D., MacDonald, G., Polyak, L., Robock, A., Serreze, M., Smol, J., Spielhagen, R., White, J., Wolfe, A., and Wolff, E.: Temperature and precipitation history of the Arctic, Quaternary Sci. Rev., 29, 1679$1715,2010$.

Minyuk, P., Brigham-Grette, J., Melles, M., Borkhodoev, V. Y., and Glushkova, O.: Inorganic geochemistry of El'gygytgyn Lake sediments (northeastern Russia) as an indicator of paleoclimatic change for the last $250 \mathrm{kyr}$, J. Paleolimnol., 37, 123-133, doi:10.1007/s10933-006-9027-4, 2007.

Murdock, K. J., Wilkie, K. M., and Brown, L. L.: Rock magnetic properties, magnetic susceptibility, and organic geochemistry comparison in core LZ1029-7 Lake El'gygytgyn, Far Eastern Russia, Clim. Past Discuss., 8, 4565-4599, doi:10.5194/cpd8-4565-2012, 2012.

Ng, S. L. and King, R. H.: Geochemistry of Lake Sediments as a Record of Environmental Change in a High Arctic Watershed, Chemie der Erde, 64, 257-275, 2004.

Nolan, M. and Brigham-Grette, J.: Basic hydrology, limnology, and meteorology of modern, J. Paleolimnol., 1, 17-35, doi:10.1007/s10933-006-9020-y, 2007.

Nolan, M., Liston, G., Prokein, P., Huntzinger, R., Brigham- Grette, J., and Sharpton, V.: Analysis of Lake Ice dynamics and morphology on Lake El'gygytgyn, Siberia, using SAR and Landsat, J. Geophys. Res., 108, 8162-8174, 2002.

Nowaczyk, N. R., Minyuk, P., Melles, M., Brigham-Grette, J., Glushkova, O., Nolan, M., Lozhkin, A. V., Stetsenko, T., Anderson, P. M., and Forman, S. L.: Magetostratigraphic results from impact crater Lake El'gygytgyn, northeastern Siberia: a 300 kyr long high-resolution terrestrial palaeoclimatic record from the Arctic, Geophys. J. Int., 150, 109-126, 2002.

Nowaczyk, N. R., Melles, M., and Minyuk, P.: A revised age model for core PG1351 from Lake El'gygytgyn, Chukotka, based on magnetic susceptibility variations tuned to northern hemisphere insolation variations, J. Paleolimnol., 37, 65-76, doi:10.1007/s10933-006-9023-8, 2007.

Ouellette, N.: Lipid biomarkers and paleovegetation determinations for the last 30,000 years at Elikchan Lake, Northeast Siberia, Bates College, 2003.

Pearson, E. J., Juggins, S., Talbot, H. M., Weckström, J., Rosen, P., Ryves, D. B., Roberts, S. J., and Schmidt, R.: A lacustrine GDGT-temperature calibration from the Scandinavian Arctic to Antarctic: Renewed potential for the application of GDGTpaleothermometry in lakes, Geochim. Cosmochim. Ac., 75, 6225-6238, 2011.

Perren, B. B., Anderson, N. J., Douglas, M. S. V., and Fritz, S. C.: The influence of temperature, moisture, and eolian activity on Holocene lake development in West Greenland, J. Paleolimnol., 48, 223-239, 2012.

Piretti, M. V., Pagliuca, G., Boni, L., Pistocchi, R., Diamante, M., and Gazzotti, T.: Investigation of 4-methyl sterols from cultured dinoflagellate algal strains, J. Phycol., 33, 61-67, 1997.

Pitcher, A., Hopmans, E. C., Mosier, A. C., Park, S. J., Rhee, S. K., Francis, C. A., Schouten, S., and Sinninghe Damsté, J. S.: 
Core and Intact Polar Glycerol Dibiphytanyl Glycerol Tetraether Lipids of Ammonia-Oxidizing Archaea Enriched from Marine and Estuarine Sediments, Appl. Environ. Microbiol., 77, 34683477, 2011.

Prokopenko, A. A. and Williams, D. F.: Deglacial methane emission signals in the carbon isotopic record of Lake Baikal, Earth Planet. Sci. Lett., 218, 135-147, doi:10.1016/S0012-821X(03)00637-X, 2004.

Rodgers, K.: Stable carbon isotope analysis of lake core sediments and lipid biomarkers as a proxy for Late Pleistocene carbon cycling at Elikchan Lake, NE Siberia, Bates College, 2005.

Schmitt, J., Schneider, R., Elsig, J., Leuenberger, D., Lourantou, A., Chappellaz, J., Kohler, P., Joos, F., Stocker, T. F., Leuenberger, M., and Fischer, H.: Carbon isotope constraints on the deglacial $\mathrm{CO}_{2}$ rise from ice cores, Science, 336, 711-714, 2012.

Schouten, S., Breteler, W. K., Blokker, P., Schoot, N., Rijpstra, W. I. C., Grice, K., Baas, M., and Sinninghe Damsté, J. S.: Biosynthetic effects on the stable carbon isotopic compositions of algal lipids: Implications for deciphering the carbon isotopic biomarker record, Geochim. Cosmochim. Ac., 62, 1397-1406, 1998.

Schouten, S., Hopmans, E. C., Schefuss, E., and Sinninghe Damsté, J. S.: Distributional variations in marine crenarchaeotal membrane lipids: a new tool for reconstructing ancient sea water temperatures?, Earth Planet. Sci. Lett., 204, 265-274, 2002.

Schouten, S., Huguet, C., Hopmans, E. C., Kienhuis, M. V. M., and Sinninghe Damsté, J. S.: Analyticalmethodology for TEX 86 paleothermometry by high-performance liquid chromatography/atmospheric pressure chemical ionization-mass spectrometry, Anal. Chem., 79, 2940-2944, 2007.

Smith, H. J., Fischer, H., Wahlen, M., Mastroianni, D., and Deck, B.: Dual modes of the carbon cycle since the Last Glacial Maximum, Nature, 400, 248-250, doi:10.1038/22291, 1999.

Sinninghe Damsté, J. S., Ossebaar, J., Abbas, B., Schouten, S., and Verschuren, D.: Fluxes and distribution of tetraether lipids in an equatorial African lake: constraints on the application of the TEX $_{86}$ palaeothermometer and BIT index in lacustrine settings, Geochim. Cosmochim. Ac., 73, 4232-4249, 2009.

Sinninghe Damsté, J. S., Rijpstra, W. I. C., Hopman, E. C., Weijers, J. W. H., Foesel, B. U., Overmann, J., and Dedysh, S. N.: 13,16Dimethyl Octacosanedioic Acid (iso-Diabolic Acid), a Common Membrane-Spanning Lipid of Acidobacteria Subdivisions 1 and 3, Appl. Environ. Microbiol., 77, 4147-4154, 2011.

Sinninghe Damsté, J. S., Ossebaar, J., Schouten, S., and Verschuren, D.: Distribution of tetraether lipids in the 25-ka sedimentary record of Lake Challa: extracting reliable $\mathrm{TEX}_{86}$ and MBT/CBT palaeotemperatures from an equatorial African lake, Quaternary Sci. Rev., 50, 43-54, 2012.

Snyder, J. A., Cherepanova, M. V., and Bryan, A.: Dynamic diatom response to changing climate $0-1.2 \mathrm{Ma}$ at Lake El'gygytgyn, far east Russian Arctic, Clim. Past Discuss., 8, 4601-4624, doi:10.5194/cpd-8-4601-2012, 2012.

Sun, Q., Chu, G., Liu, M., Xie, M., Li, S., Ling, Y., Wang, X., Shi, L., Jia, G., and Lü, H.: Distributions and temperature dependence of branched glycerol dialkyl glycerol tetraethers in recent lacustrine sediments from China and Nepal, J. Geophys. Res., 116, G01008, doi:10.1029/2011JG001753, 2011.

Swann, G. E. A, Leng, M.J., Juschus, O., Melles, M., BrighamGrette, J., and Sloane, H. J.: A combined oxygen and sili- con diatom isotope record of Late Quaternary change in Lake El'gygytgyn, North East Siberia, Quaternary Sci. Rev., 29, 774 786, 2010.

Tierney, J. E. and Russell, J. M.: Distributions of branched GDGTs in a tropical lake system: implications for lacustrine application of the MBT/CBT paleoproxy, Org. Geochem., 40, 1032-1036, 2009.

Tierney, J. E., Russell, J. M., Eggermont, H., Hopmans, E. C., Verschuren, D., and Sinninghe Damsté, J. S.: Environmental controls on branched tetraether lipid distributions in tropical East African lake sediments, Geochim. Cosmochim. Ac., 74, 49024918, 2010a.

Tierney, J. E., Russell, J. M., and Huang, Y. S.: A molecular perspective on Late Quaternary climate and vegetation change in the Lake Tanganyika basin, East Africa, Quaternary Sci. Rev., 29, 787-800, 2010b.

Tierney, J. E., Schouten, S., Pitcher, A., Hopmans, E. C., and Sinninghe Damsté, J. S.: Core and intact polar glycerol dialkyl glycerol tetraethers (GDGTs) in Sand Pond, Warwick, Rhode Island (USA): Insights into the origin of lacustrine GDGTs, Geochim. Cosmochim. Ac., 77, 561-581, 2012.

Tipple, B. J. and Pagani, M.: A 35 Myr North American leaf-wax compound-specific carbon and hydrogen isotope record: Implications for C4 grasslands and hydrologic cycle dynamics, Earth Planet. Sci. Lett., 299, 250-262, 2010.

Versteegh, G. J. M., Bosch, H.-J., and de Leeuw, J. W.: Potential palaeoenvironmental information of $\mathrm{C} 24$ to $\mathrm{C} 36$ mid-chain diols, keto-ols and mid-chain hydroxy fatty acids; a critical review, Org. Geochem., 27, 1-13, 1997.

Vincent, W. and Laybourn-Parry, J.: Polar Lakes and Rivers, Limnology of Arctic and Antarctic Aquatic Ecosystems, edited by: Vincent, W. and Laybourn-Parry, J., Oxford University Press, Oxford, 2008.

Volkman, J. K.: A review of sterol markers for marine and terrigenous organic matter, Org. Geochem., 9, 83-99, 1986.

Volkman, J. K., Johns, R., Gillan, F., and Perry, G.: Microbial lipids of an intertidal sediment - I. Fatty acids and hydrocarbons, Geochim. Cosmochim. Ac., 44, 1133-1143, 1980.

Volkman, J. K., Barrett, S. M., Dunstan, G. A., and Jeffrey, S. W.: $\mathrm{C}_{30}-\mathrm{C}_{32}$ alkyl diols and unsaturated alcohols in microalgae of the class Eustigmatophyceae, Org. Geochem., 18, 131-138, 1992.

Volkman, J. K., Barrett, S. M., Blackburn, S. I., Mansour, M. P., Sikes, E. L., and Gelin, F.: Microalgal biomarkers: A review of recent research developments, Org. Geochem., 29, 1163-1179, 1998.

Weijers, J. W. H., Schouten, S., van den Donker, J. C., Hopmans, E. C., and Sinninghe Damsté, J. S.: Environmental controls on bacterial tetraether membrane lipid distribution in soils, Geochim. Cosmochim. Ac., 71, 703-713, 2007.

Whiticar, M. J.: Carbon and hydrogen isotope systematics of bacterial formation and oxidation of methane, Chem. Geol., 161, 291-314, doi:10.1016/S0009-2541(99)00092-3, 1999.

Wilkie, K. M. K.: Compound-specific hydrogen isotopes of lipid biomarkers in Lake El'gygytgyn, NE Russia, Electronic Doctoral Dissertations for UMass Amherst. Paper AAI3518289, 2012.

Withers, N.: Dinoflagellate sterols, in: Marine Natural Products: Chemical and Biological Perspectives, Academic Press, New York, 87-130, 1983. 
Xu, Y., Simoneit, B. R. T., and Jaffé, R.: Occurrence of long-chain $\mathrm{n}$-alkenols, diols, keto-ols and sec-alkanols in a sediment core from a hypereutrophic, freshwater lake, Org. Geochem., 38, 870883, 2007.
Zink, K. G., Vandergoes, M. J., Mangelsdorf, K., DieffenbacherKrall, A. C., and Schwark, L.: Application of bacterial glycerol dialkyl glycerol tetraethers (GDGTs) to develop modern and past temperature estimates from New Zealand lakes, Org. Geochem., 41, 1060-1066, 2010. 